Santa Clara University

Scholar Commons

Accounting

Leavey School of Business

4-2017

\title{
Country-level institutions, firm value, and the role of corporate social responsibility initiatives
}

Sadok El Ghoul

Omrane Guedhami

Yongtae Kim

Santa Clara University, y1kim@scu.edu

Follow this and additional works at: http://scholarcommons.scu.edu/accounting

Part of the Accounting Commons

\section{Recommended Citation}

Ghoul, S. E., Guedhami, O., \& Kim, Y. (2017). Country-level institutions, firm value, and the role of corporate social responsibility initiatives. Journal of International Business Studies, 48(3), 360-385. https://doi.org/10.1057/jibs.2016.4

The final publication is available at Springer via https://doi.org/10.1057/jibs.2016.4.

This Article is brought to you for free and open access by the Leavey School of Business at Scholar Commons. It has been accepted for inclusion in Accounting by an authorized administrator of Scholar Commons. For more information, please contact rscroggin@scu.edu. 


\title{
Country-Level Institutions, Firm Value, and the Role of Corporate Social Responsibility Initiatives *
}

\author{
Sadok El Ghoul \\ Associate Professor, Campus Saint-Jean, University of Alberta \\ 8406, Rue Marie-Anne-Gaboury (91 Street), Edmonton, AB T6C 4G9, Canada \\ elghoul@ualberta.ca. Phone: 780-465-8725, Fax: 780-465-8760 \\ Omrane Guedhami \\ Associate Professor, Moore School of Business, University of South Carolina \\ 1705 College Street, Columbia, SC 29208, U.S.A. \\ omrane.guedhami@moore.sc.edu, Phone: 803-777-2175, Fax: 803-777-3609 \\ Yongtae Kim \\ Professor, Leavey School of Business, Santa Clara University \\ 500 El Camino Real, Santa Clara, CA 95053, U.S.A. \\ y1kim@scu.edu, Phone: 408-554-4667. Fax: 408-554-2331
}

\footnotetext{
* We thank two anonymous reviewers, Jonathan Doh (Editor), Nargess Kayhani, Tammy Madsen, Niki den Nieuwenboer, Carrie Pan, Sanjay Patnaik, Andrew Spicer, and participants at the 2015 Harvard Business School (HBS)/Journal of International Business Studies workshop on "International Business Responses to Institutional Voids", 2015 SSFII Social and Sustainable Finance and Impact Investing conference at the Said Business School, University of Oxford, 2015 FMA European Conference, and at the 2014 Academy of International Business Meeting for constructive comments. We appreciate the generous financial support of the Social Sciences and Humanities Research Council of Canada.
} 


\title{
Country-Level Institutions, Firm Value, and the Role of Corporate Social Responsibility Initiatives
}

\begin{abstract}
Drawing on transaction cost theories and the resource-based view of a firm, we posit that the value of corporate social responsibility (CSR) initiatives is greater in countries where an absence of market-supporting institutions increases transaction costs and limits access to resources. Using a large sample of 11,672 firm-year observations representing 2,445 unique firms from 53 countries during 2003-2010 and controlling for firm-level unobservable heterogeneity, we find supportive evidence that CSR is more positively related to firm value in countries with weaker market institutions. We also provide evidence on the channels through which CSR initiatives reduce transaction costs. We find that CSR is associated with improved access to financing in countries with weaker equity and credit markets, greater investment and lower default risk in countries with more limited business freedom, and longer trade credit period and higher future sales growth in countries with weaker legal institutions. Our findings provide new insights on non-market mechanisms such as CSR through which firms can compensate for institutional voids.
\end{abstract}




\section{INTRODUCTION}

Negotiating, monitoring, and enforcement costs arise due to transaction difficulties in the exchange process (Jones \& Hill, 1988; Klein, Crawford, \& Alchian, 1978; Williamson, 1975). Transaction cost theories suggest that specialized intermediaries, or institutions, emerge to mitigate the various costs associated with market failures (Coase, 1937; Williamson, 1985). These institutions support the effective functioning of the market by allowing firms and individuals to engage in transactions without incurring undue costs or risks (Meyer, Estrin, Bhaumik, \& Peng, 2009). However, if capital markets, regulatory systems, and contract enforcement mechanisms are absent or weak, as is often the case in emerging markets, firms must develop strategic responses to overcome these voids (Khanna \& Palepu, 1997, 2011). ${ }^{1}$

Prior studies emphasize several such responses to institutional voids: the creation of business groups that internalize the functions typically carried out by external markets (Chang \& Hong, 2000; Fisman \& Khanna, 2004; Leff, 1978); the formation of a strategic alliance with a foreign multinational firm from a country with strong monitoring institutions (Siegel, 2009); geographical clustering that creates local business environments (Karna, Taübe, \& Sonderegger, 2013); and internationalization to access more efficient and munificent foreign markets (Luo \& Tung, 2007). Notably, all of these strategies are "market" responses to institutional voids. "Nonmarket" strategies for addressing institutional voids, in contrast, have received little attention to date. In an effort to help fill this gap, we examine whether the strategic value of corporate social responsibility (CSR) is higher in countries with greater institutional voids. If CSR initiatives can help firms reduce the transaction costs arising from institutional voids, then the strategic value of CSR should be higher in countries with weak market-supporting institutions.

Prior literature provides mixed views on the role of CSR. In the spirit of shareholder theory (e.g., Friedman, 1962, 1970), early literature views CSR as a waste of resources that 
reduces profits. Similarly, CSR might be the outcome of an agency conflict between shareholders and managers (Jensen \& Meckling, 1976): CSR decisions may be driven by managers' own social preferences or desire to establish relationships with specific stakeholders. More recent research, however, emphasizes the potential value of CSR to shareholders. In particular, instrumental stakeholder theory argues that CSR efforts can help firms obtain necessary resources or stakeholder support (e.g., Jones, 1995). CSR may also improve efficiency and enhance a firm's reputation, brand, and trust (e.g., Barney, 1991; Hart, 1995; Porter, 1991; Porter \& Kramer, 2006, 2011; Russo \& Fouts, 1997), and attract new customers (Lev, Petrovits, \& Radhakrishnan, 2010).

We posit that CSR initiatives help reduce transaction costs and improve access to resources. Because resources are important for a firm's competitive advantage (Hill \& Jones, 1989; Robins, 1992; Williamson, 1985), reducing transaction costs can help create value (Foss \& Foss, 2005). We further posit that the role of CSR in reducing transaction costs and improving access to resources is likely to be more pronounced in countries with institutional voids, as the absence of market-supporting institutions results in high transaction costs in these countries. ${ }^{2}$ The rationale is as follows. If a country lacks strong equity and credit markets, firms will have difficulty raising external capital due to agency costs and information asymmetry problems. By increasing transparency (Dhaliwal, Li, Tsang, \& Yang, 2011; Gelb \& Strawser, 2001; Kim, Park, \& Wier, 2012) and mitigating managerial opportunism (Bénabou \& Tirol, 2010), CSR activities reduce agency costs and information asymmetry problems and thus help firms access financing at better terms (Cheng, Ioannou, \& Serafeim, 2014), which facilitates their growth. Similarly, if the state frequently intervenes in business operations, giving companies limited freedom, managers will have difficulty making value-maximizing investments. By signaling a 
commitment to environmental sustainability and community wellbeing, CSR can generate community support and reduce roadblocks to positive net present value (NPV) investments. Trust and loyalty engendered by stable relations with external stakeholders create social capital, which can also reduce a firm's risks and help the firm survive during tough times (Miller, Lee, Chang, \& Le Breton-Miller, 2009; Saxton, 1997). Finally, if contracts are not enforced by an effective legal system, consumers and suppliers cannot recover losses in the event the firm reneges on the terms of its contracts. Under such circumstances, suppliers will be reluctant to extend trade credit and customers will be hesitant to enter into long-term product or service agreements. By signaling a firm's commitment not to exploit its stakeholders (Brammer \& Pavelin, 2006; Du, Bhattacharya, \& Sen, 2011; Zhang, Ma, Su, \& Zhang, 2014), CSR can help increase consumers' confidence in exchange agreements and suppliers' willingness to extend trade credit.

Using a sample of 11,672 firm-year observations representing 2,445 firms from 53 countries over the period 2003-2010, we first examine whether the valuation effects of CSR vary with the strength of country-level, market-supporting institutions. In particular, we examine the relation between CSR and Tobin's q, our proxy for firm value, as this relation summarizes the strategic value of CSR operating through various channels (Servaes \& Tamayo, 2013; Waddock \& Graves, 1997). In line with our prediction, we find that the strategic value of CSR is greater in countries with greater institutional voids.

We next examine the channels through which CSR can help firms overcome institutional voids. To do so, we identify specific economic resources that are influenced by specific types of institutional voids. We then examine whether the role of CSR in facilitating access to a given resource, and hence in improving a firm's competitive advantage, is more pronounced in 
countries with greater institutional voids. We find that the relation between CSR and both a firm's access to financing and its growth through external financing is more pronounced in countries with weaker equity and credit markets. Also, the relation between CSR and both firm investment and default risk is more pronounced in countries with more limited business freedom, and the relation between CSR and both trade credit and future sales growth is more pronounced in countries with weaker legal institutions.

The rest of the paper is organized as follows. The second section summarizes prior literature and develops a theory on the role of CSR in overcoming institutional voids. The third section describes the sample and research methodology. The fourth section presents our main results. The fifth section provides robustness checks. Finally, the last section discusses implications of the findings, contributions, limitations, and directions for future research.

\section{PRIOR LITERATURE AND HYPOTHESES}

\section{Transaction Costs, the Role of Institutions, and Institutional Voids ${ }^{3}$}

Transaction costs comprise the negotiating, monitoring, and enforcement costs incurred for an exchange between two parties to take place (Jones \& Hill, 1988). The sources of these costs are the transaction difficulties that may be present in the exchange process (Klein et al., 1978; Williamson, 1975). ${ }^{4}$ For example, gathering information, deciding whom to bargain with, and protecting existing contracts all impose significant costs and risk (Coase, 1960). Williamson (1985) argues that just as friction absorbs energy and reduces the efficiency of a mechanical system, transaction costs reduce economic efficiency and the potential value of an exchange.

Transaction cost theories suggest that specialized intermediaries, or institutions, emerge to resolve information and contracting problems and thus reduce transaction costs (Akerlof, 
1970; Coase, 1937; Williamson, 1985). Such institutions support the effective functioning of markets by allowing firms and individuals to engage in transactions without incurring undue costs (Meyer et al., 2009). While the quality of institutions varies even in developed markets, firms operating in emerging markets face a number of institutional voids (Khanna \& Palepu, 2011). Absent strong equity and credit markets with information intermediaries such as financial analysts, investment banks, and the financial press, firms may not be able to raise adequate capital due to information asymmetry problems (Meyer et al., 2009). Moreover, if the state intervenes extensively in business operations, managers may have difficulty predicting the actions of regulatory bodies, which could impair their ability to make value-maximizing investment decisions. Direct government involvement, through state control of enterprises or banks, may further distort firms' ability to compete fairly (Kuppuswamy, Serafeim, \& Villalonga, 2012). Regulatory roadblocks can also impede the ability of firms to exploit new business opportunities that might emerge through the introduction of new products or services (Kuppuswamy et al., 2012). Finally, under weak legal institutions, consumers have limited ability to seek redress if a product fails to deliver on its promise, which can lead to product market failure (Khanna \& Palepu, 1997). In short, where market-supporting institutions are absent or weak, firms must develop solutions to overcome market failures.

Prior studies on strategies to address institutional voids focus primarily on "marketbased" approaches. For example, a number of studies suggest that by internalizing product and capital market intermediation, large and diversified conglomerates or business groups are efficient responses to transaction costs (Chang \& Hong, 2000; Fisman \& Khanna, 2004; Khanna \& Palepu, 2000a; Leff, 1978; Peng, Lee, \& Wang, 2005). Siegel (2009) further suggests that forming a strategic alliance with a foreign multinational firm from a country with stronger legal 
institutions can improve a firm's access to capital, as shared investment motivates the foreign multinational to monitor investment quality. Karna et al. (2013) argue that in an emerging economy context, geographical clusters can create a local business environment that helps multinational corporations overcome institutional voids. Similarly, Luo and Tung (2007) suggest that emerging-market firms can escape from home-country institutional voids and use aggressive internalization strategies to access more efficient foreign markets.

However, these market-based strategies are associated with other significant costs. For example, unrelated diversification may lead to inefficient business decisions, and poorly developed markets for corporate control in emerging markets allow inefficiencies to persist (La Porta, Lopez-de-Silanes, \& Shleifer, 1999; La Porta, Lopez-de-Silanes, Shleifer, \& Vishny, 1998). Conflicts between controlling family shareholders and minority shareholders can exacerbate this problem (Khanna \& Palepu, 2000b). In line with this argument, empirical evidence suggests that Indian business group affiliates are more difficult to monitor than otherwise comparable unaffiliated firms (Khanna \& Palepu, 2000c).

The above literature review reveals that prior studies focus primarily on market responses to institutional voids, with potential non-market strategies such as CSR receiving limited attention. Given this gap in the literature, we develop a theoretical framework that can help us understand the role of CSR in mitigating transaction costs, facilitating firms' access to resources, and ultimately improving firms' competitive advantage in countries with institutional voids.

\section{The Strategic Value of CSR}

In this paper, we adopt the definition of CSR proposed by McWilliams and Siegel (2001): actions that further the needs or goals of stakeholder groups or the larger social collective 
beyond the interests of the firm or what is required by law. Examples of CSR activities include going beyond legal requirements in a firm's human resource or recycling programs, exerting efforts to reduce pollution, supporting local communities, and embodying products with social attributes or characteristics.

The strategic value of CSR is well recognized in the literature. Baron (2001) argues that companies compete for socially responsible customers by explicitly linking their social contributions to product sales. Porter and $\operatorname{Kramer}(2002,2006)$ argue that corporate philanthropy can be leveraged to enhance a firm's competitive advantage. Doh, Lawton, and Rajwani (2012) similarly suggest that a firm's social and environmental practices can enhance its competitive advantage. A body of literature examines the relation between CSR and financial performance. Waddock and Graves (1997) report a positive and significant relation between CSR and future as well as prior financial performance. Pava and Krausz (1996) also find that firms perceived as socially responsible perform as well as or better than firms that do not engage in socially responsible activities. ${ }^{5}$

In the next section, we develop a theoretical framework that predicts a greater strategic value of CSR initiatives in countries with greater institutional voids. We diagram our theoretical framework in Figure 1.

\section{Figure 1 about here}

\section{The Role of CSR in Filling Institutional Voids}

The resource-based view depicts the firm as a unique collection of resources (Penrose, 1995; Wernerfelt, 1984), and posits that the possession of key resources allows the firm to achieve and maintain a competitive advantage (Hill \& Jones, 1989; Robins, 1992; Williamson, 
1985). The resource combination of a firm is influenced by transaction costs (Teece, 1982;

Williamson, 1991) because transaction costs such as search, negotiation/contract, and monitoring/enforcement costs prevent firms from acquiring resources (Reeve, 1990; Yao, 1988). As resources are important for a firm's competitive advantage, strategic opportunities arise from reducing transaction costs. That is, while transaction costs are a major source of value dissipation, reducing transaction costs can create value (Foss \& Foss, 2005).

Limited market mechanisms in countries with institutional voids increase transaction costs. Firms in these countries thus have strong incentives to minimize transaction costs. By developing close social connections with external stakeholders who provide resources, CSR may help fill gaps in the political, social, and economic infrastructure of emerging markets (Miller et al., 2009), reducing the firm's transaction costs.

Prior studies show that investors associate firms investing in CSR with high transparency (Dhaliwal et al., 2011; Gelb \& Strawser, 2001; Kim et al., 2012) and low short-term opportunism (Bénabou \& Tirol, 2010), which helps lower perceived agency costs and information asymmetry. Lower agency costs and information asymmetry facilitate access to external capital (Cheng et al., 2014; El Ghoul, Guedhami, Kwok, \& Mishra, 2011), which in turn accelerate firm growth.

Ongoing, positive relationships with communities resulting from CSR can also reduce compliance costs (Belkaoui, 1976; Bragdon \& Marlin, 1972; Freedman \& Stagliano, 1991; Shane \& Spicer, 1983; Spicer, 1978) and decrease a firm's exposure to risk (Godfrey, 2005; Miller et al., 2009; Saxton, 1997). Lower investment risk allows firms to realize valuable investment opportunities and increase their chances of survival. 
In addition, CSR initiatives help reduce contracting costs by signaling a firm's commitment to act in accordance with stakeholders' expectations (Brammer \& Pavelin, 2006; Du et al., 2011; Zhang et al., 2014), which may evoke reciprocal commitment by suppliers through trade credit. CSR investments also result in greater trust and reputation, which can help increase customer loyalty and attract new customers (Lev et al., 2010).

In summary, CSR can reduce transaction costs and increase access to capital, social, and reputational resources that are hard to obtain in countries with institutional voids. Thus, CSR provides competitive advantage for firms operating in these countries. ${ }^{6}$ Just as internal markets available to diversified entities such as business groups are relatively more useful when specialized intermediaries are absent and functioning of external markets is thus compromised (Ricart, Enright, Ghemawat, Hart, \& Khanna, 2004), these effects of CSR are expected to be more pronounced in countries with institutional voids, where transaction costs are higher and, as a result, access to these key resources is limited. Thus the strategic value of CSR should be greater in countries with greater institutional voids, consistent with the conjecture of Rodriguez, Siegel, Hillman, and Eden (2006) that cross-country institutional differences lead to different expectations and different returns to CSR. ${ }^{7}$ The fact that not many firms have capabilities to invest in CSR in countries with institutional voids also adds to a greater competitive advantage of firms that do invest in CSR (Flammer, 2015). This discussion leads to our first hypothesis:

Hypothesis 1. CSR and firm value are more positively associated in countries with weaker market-supporting institutions than in countries with stronger market-supporting institutions.

CSR can improve firm value in the absence of strong market-supporting institutions through several channels. Inefficiencies in stock and credit markets are characterized by high 
agency costs and information asymmetry. High agency costs and information asymmetry constrain access to external financing. Since CSR increases transparency (Dhaliwal et al., 2011; Gelb \& Strawser, 2001; Kim et al., 2012) and reduces short-term opportunism (Bénabou \& Tirole, 2010), it improves firm access to financing (Cheng et al., 2014). We expect this role of CSR to be greater in countries with weaker capital markets, where a lack of information intermediaries results in greater information asymmetry and agency problems. This leads to our second hypothesis:

Hypothesis 2. Access to capital through new equity or debt issues is more positively associated with CSR in countries with weaker capital markets than in countries with stronger capital markets.

Improved access to financial resources allows firms to grow through external financing. As the role of CSR in facilitating access to external financing is greater in countries with weaker capital markets, the effect of CSR on excess growth through external financing will also be greater in such countries. More formally:

Hypothesis 3. Excess growth through external financing is more positively associated with CSR in countries with weaker capital markets than in countries with stronger capital markets. Next, in countries with limited business freedom, the costs of complying with regulations are high. Government bureaucracies often make entry too expensive or time-consuming. Further, the risk of assets being nationalized may discourage firms from making investments (Fisman \& Khanna, 2004).

CSR helps develop deeper relationships with external stakeholders and build social capital (Clarkson, 1995; McWilliams \& Siegel, 2001; Wood, 1991). Social capital generated by 
trust and loyalty reduces uncertainty faced by firms as it increases preferential treatment by social actors within the community or government (Oliver, 1991) and deflects adverse attention from constituents that could impair opportunities (Meyer \& Rowan, 1977). For example, commitment to environmental sustainability and social wellbeing can mobilize community support, easing tension between firms and regulators and reducing compliance costs. We thus expect the effect of CSR on the level of investment to be more pronounced in countries with more limited business freedom, where high compliance costs and investment risk reduce firms' incentives and ability to make value-maximizing investments:

Hypothesis 4. The level of investment is more positively associated with CSR in countries with more limited business freedom than in countries with greater business freedom.

Prior studies also suggest that CSR can help firms avoid costly government fines (Belkaoui, 1976; Bragdon \& Marlin, 1972; Freedman \& Stagliano, 1991; Shane \& Spicer, 1981; Spicer, 1978), reducing a firm's exposure to risk (Godfrey, 2005). The social capital engendered by stable relations with external stakeholders can also reduce the risks associated with a firm and help a firm to survive during tough times (Miller et al., 2009; Saxton, 1997). The ability to realize valuable investment projects also increases the chance of survival. Thus, we expect firms that invest in CSR to have a greater chance of survival. Again, as compliance costs and business risk are greater in countries with more limited business freedom, the positive relation between CSR and the chance of survival would be more pronounced in such countries:

Hypothesis 5. The chance of survival is more positively associated with CSR in countries with more limited business freedom than in countries with greater business freedom. 
Weak legal institutions and limited enforcement of liability laws increase contracting costs. When contracts are not enforced by an effective legal system, consumers and suppliers cannot recover losses in the event the firm reneges on the terms of its contracts, leading to product market failure. For instance, consumers will have concerns about product quality and long-term service agreements, and suppliers will have concerns about extending trade credit. As a result, contracting costs are high in countries with weaker legal institutions and more limited property rights. That is, suppliers are reluctant to extend trade credits and customers are hesitant to enter into long-term product or service agreements.

Prior studies suggest that companies engage in CSR in order to enhance their reputation, brand, and trust (e.g., Porter, 1991; Porter \& Kramer, 2006, 2011; Russo \& Fouts, 1997). Ongoing, long-term relationships with external stakeholders engender trust and goodwill, and reduce transaction costs (Adler \& Kwon, 2002; Nahapiet \& Ghoshal, 1998). For example, investing in stakeholder relations can lead to customer or supplier loyalty (Hillman \& Keim, 2001).

CSR initiatives signal a firm's commitment to act in accordance with stakeholders' expectations (Brammer \& Pavelin, 2006; Du et al., 2011; Zhang et al., 2014), which may evoke reciprocal commitment. When reputation and trust are lacking, suppliers may not extend trade credit to the firm. Since the need to reduce transaction costs is greater in countries with greater institutional voids, we expect the relation between CSR and the extent of trade credit to be more pronounced in countries with weaker legal rights and more limited property rights. More formally: 
Hypothesis 6 . The trade credit period is more positively associated with CSR in countries with weaker legal institutions and more limited property rights than in countries with stronger legal institutions and more secure property rights.

Intangible resources such as reputation, brand, and trust may attract new customers (e.g., socially conscious consumers), increase a firm's profitability, and enhance its competitiveness. As CSR initiatives help build customer loyalty and attract new customers (Lev et al., 2010) and the need for reducing contracting costs is greater in countries with weaker legal systems and more limited property rights, we expect the positive association between CSR and future sales growth to be more pronounced in such countries:

Hypothesis 7. Future sales growth is more positively associated with CSR in countries with weaker legal institutions and more limited property rights than in countries with stronger legal institutions and more secure property rights.

\section{SAMPLE AND RESEARCH METHODOLOGY}

\section{Sample Construction}

To test the prediction that CSR is more valuable for firms that operate in countries with weaker institutions, we begin by collecting data on CSR from Thomson Reuters' ASSET4. This database "provides objective, relevant and systematic environmental, social and governance (ESG) information" ${ }^{\prime 8}$ for over 3,400 listed companies included in S\&P 500, Russell 1000, MSCI Europe, FTSE 250, ASX 300, MSCI World Index, and 250 MSCI emerging market companies. Thomson Reuters states that "using only publicly available information, our $100+$ specially trained analysts scour through company reports and other public sources, and transform the results into comparable and consistent units to enable assessment of different entities." ASSET4 data have been used in recent CSR studies of U.S. and non-U.S. companies (e.g., Cheng et al., 
2014; Ioannou \& Serafeim, 2012; Luo, Wang, Raithel, \& Zheng, 2015). ${ }^{9}$ We then match the ASSET4 data with Compustat North America and Global files to obtain financial data. We exclude firms in the financial industry (SIC codes between 6000 and 6999) because their regulatory setting is different from that of other firms. We also drop observations with missing values for the regression variables. This procedure yields a sample of 11,672 firm-years representing 2,445 firms from 53 countries over the period 2003-2010.

Table 1 provides the sample distribution by country, year, and Fama and French (1997) industry classification. Panel A shows that there is wide variation in the number of firm-years across countries: the U.S. is the most representative country, accounting for 3,658 firm-years, while Panama and Qatar are the least representative countries, with just one firm-year each. ${ }^{10}$ Panel B shows that the number of firm-years increases steadily over the sample period, from 644 in 2003 to 2,344 in 2010. Panel C shows that the sample is fairly dispersed across industries, with no single industry group representing more than $10 \%$ of the sample observations.

\section{Table 1 about here}

\section{Variable Measurements}

Firm value. We examine the relation between CSR and firm value because it captures the cumulative valuation effect of CSR operating through various channels. Following extensive prior research in economics, finance, and strategy (e.g., Morck, Shleifer, \& Vishny, 1988; Servaes \& Tamayo, 2013; Waddock \& Graves, 1997), we measure firm value using Tobin's q (TOBQ), which is the market value of the firm divided by the replacement value of the firm's assets. We compute Tobin's q as market value of equity plus book value of assets minus book value of equity, all divided by book value of assets. This measure is similar to that in Servaes and 
Tamayo (2013), except we do not subtract deferred taxes from the numerator, as this variable is missing for a significant number of firms in Compustat Global.

Channels. Hypotheses 2 through 7 predict that various firm-level outcomes (the channels) are more positively related to CSR in countries with weaker market-supporting institutions. These firm-level outcomes represent resources and competitive advantages achieved through CSR initiatives as CSR investments reduce transaction costs. We define our proxies for these firm-level outcomes below.

Equity issuance. Following McLean, Zhang, and Zhao (2012) we measure the net amount of equity issued as the change in book equity, plus the change in deferred taxes, minus the change in retained earnings. To rule out trivial changes in equity, we construct Equity Issue as a dummy variable equal to 1 if the net amount of equity issued divided by lagged assets exceeds $1 \%$, and 0 otherwise.

Excess growth. Following Demirgüç-Kunt and Maksimovic (2002), we first construct the externally financed growth rate as the difference between the firm's actual growth rate (measured as sales growth) minus the maximum growth rate that can be financed if the firm relies only on internal resources and maintains its dividend (measured as $R O A /(1-R O A))$. We then define Excess Growth as the geometric average of the externally financed growth rate over the next two years (Durnev \& Kim, 2005).

Debt issuance. We follow McLean et al. (2012) to measure the net amount of debt issued as the change in total debt. Debt Issue is a dummy variable equal to 1 when the net amount of debt issued divided by lagged assets exceeds $1 \%$, and 0 otherwise. 
Investment. We capture investment intensity (Investment) using the ratio of capital expenditures to lagged property, plant, and equipment (Cleary, 1999).

Probability of default. We capture the probability of bankruptcy using the Black-Scholes-Merton option-pricing model as implemented by Hillegeist, Keating, Cram, and Lundstedt (2004). This model values equity as a European call option on the value of the firm's assets. The value of equity, $V_{E}$, is obtained as $V_{E}=V_{A} e^{-\delta T} N\left(d_{1}\right)-X e^{-T} N\left(d_{2}\right)+\left(1-e^{-\delta T}\right) V_{A}$, where $N($.$) is the$ standard cumulative normal distribution, $d_{1}=\left[\ln \left(V_{A} / X\right)+\left(r-\delta+\sigma_{A}^{2} / 2\right) T\right] / \sigma_{A} \sqrt{T}, d_{2}=$ $d_{1}-\sigma_{A} \sqrt{T}, V_{A}$ is the value of asset, $\delta$ is the dividend rate measured as dividends to $V_{A}, X$ is the face value of debt measured as total liabilities, $T$ is assumed to be equal to 1 year, $r$ is the riskfree rate measured as the yield on 1-year constant-maturity U.S. Treasury securities, and $\sigma_{A}$ is the volatility of asset returns. $V_{A}$ and $\sigma_{A}$ are estimated by solving the equity value equation above and the optimal hedge equation: $\sigma_{E}=\left[V_{A} e^{-\delta T} N\left(d_{1}\right) \sigma_{A}\right] / V_{E}$, where $\sigma_{E}$ is the volatility of equity returns computed over the previous year. Equity returns are obtained from CRSP (for U.S. firms) and Compustat Global (for non-U.S. firms). The firm's asset returns are then given by $\mu=$ $\max \left[\left(V_{A, t} / V_{A, t-1}\right)-1, r\right]$. Finally, the probability of default (Bankruptcy) is given by $N\left(\frac{-\ln \left(V_{A} / X\right)+\left(\mu-\delta-\left(\sigma_{A}^{2} / 2\right)\right) T}{\sigma_{A} \sqrt{T}}\right)$.

Payable turnover. We calculate the frequency with which the firm pays its suppliers (Payable Turnover) as the ratio of cost of goods sold to accounts payable. Payable Turnover is inversely related to the length of the trade credit period extended by suppliers.

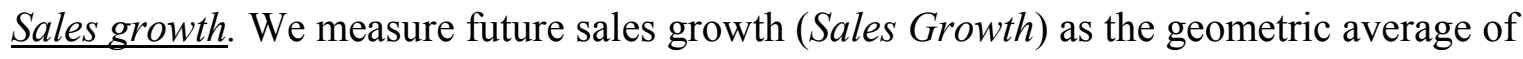
growth in sales over the next two years. 
CSR. ASSET4 data contain scores on environmental, social, economic, and governance performance. For each firm, over 250 objective indicators are used to calculate these four performance scores. Following previous studies (e.g., Ioannou \& Serafeim, 2012; Luo et al., 2015), we capture a firm's overall CSR performance score (CSR_P) as the average of its environmental performance score and social performance score. ${ }^{11}$ The environmental performance score measures a firm's impact on living and non-living natural systems including the air, land, and water, as well as complete ecosystems. This measure captures, for example, resource reduction, emission reduction, and product innovation benefiting the environment. The social performance score measures the extent of trust and loyalty between a firm and its workforce, customers, and society through investment in customer/product responsibility, community, human rights, diversity, employee training and development, health and safety, and employment quality. The original ASSET4 scores each lie between 0 and 100. We normalize $C S R_{-} P$ such that it ranges between 0 and 1.

Country-level institutions. Prior studies on institutional voids consider various measures of the strength of market-supporting institutions. ${ }^{12}$ Consistent with our theoretical framework on the channels through which CSR mitigates transaction costs under institutional voids, and following Meyer et al. (2009), we focus on proxies for the strength of market-supporting institutions in the areas of stock and credit market, regulatory system, and legal system \& property rights.

To do so, we rely on the IMD World Competitiveness Yearbook (WCY) and Economic Freedom of the World (EFW) data from the Fraser Institute. ${ }^{13}$ More specifically, we use the following four indices: (1) WCY's Stock Market Efficiency, which indicates whether stock markets provide adequate financing to companies, (2) WCY's Credit Market Efficiency, which 
captures whether credit is readily available to businesses, (3) EFW's Business Freedom, which assesses freedom from regulations as reflected by administrative requirements, bureaucratic costs, ease of entry, bribes/other extra payments required, licensing restrictions, and the cost of tax compliance, and (4) EFW's Legal System \& Property Rights, which evaluates the quality of the legal system based on judicial independence, impartial courts, protection of property rights, military interference in the rule of law and politics, integrity of the legal system, legal enforcement of contracts, regulatory restrictions on the sale of real property, reliability of police, and business costs of crime. Each of these indices ranges from 0 to 10 . Higher values indicate more efficient stock markets, easier access to external financing, fewer regulatory hurdles to firm entry and operations, and better contract and property rights enforcement. ${ }^{14}$

Appendix A summarizes variable definitions and data sources. Appendix B reports the values for each of the institutional indices by country, averaged over the sample period. Table 2 provides summary statistics for Tobin's q and the CSR measure by country in Panel A, and for the firm-level variables, the natural logarithm of GDP, and the country-level institutional indices in Panel B. Tobin's q, the CSR measure, and the country-level institutional indices all display a high degree of variation across sample observations.

\section{Table 2 about here}

\section{Test Models}

We argue in Hypothesis 1 that CSR performance and firm value are more positively associated in countries with weaker market-supporting institutions than in countries with stronger ones. To examine how the strength of a country's market-supporting institutions (in the 
areas of stock and credit market, regulatory system, and legal system efficiency) affects the relation between CSR and firm value, we estimate the following regression model:

$$
\begin{aligned}
\text { TOB }_{i t}=\alpha_{0} & +\alpha_{1} \text { CSR_P }_{i t-1}+\alpha_{2} \text { Institution }_{i t-1}+\alpha_{3} \text { CSR }_{-} P_{i t-1} \times \text { Institution }_{i t-1} \\
& +\sum_{k=1}^{6} \theta_{k} \text { CONTROL }_{k i t-1}+\mu_{i}+\mu_{t}+\varepsilon_{i t}
\end{aligned}
$$

where $i$ indexes firms, $t$ indexes years, TOBQ is Tobin's q, CSR_P is our proxy for CSR performance, Institution is one of the four country-level institutional indices discussed above, CONTROL includes the firm- (SIZE, ROA, LEV, R\&D/S, SGR) and country-level (LOG_GDP) control variables, $\mu_{i}$ denotes firm fixed effects, $\mu_{t}$ denotes year fixed effects, and $\varepsilon$ is an error term. $\alpha_{3}$, the coefficient on the interaction between the institutional variable (Institution) and the CSR proxy $\left(C S R_{-} P\right)$ gives the value implication of CSR across countries with varying degrees of institutional strength.

We include control variables commonly used in firm value regressions to ensure that the coefficient on CSR does not pick up the effects of other correlated factors. Larger firms are more diversified and, thus, suffer more from the diversification discount (Claessens, Djankov, Fan, \& Lang, 2002). We measure firm size as the natural logarithm of total assets in millions of US\$ $(S I Z E)$. Profitable firms should have higher valuations (Jayachandran, Kalaignanam, \& Eilert, 2013). We gauge profitability using return on assets, i.e., the ratio of net income before extraordinary items to total assets $(R O A)$. Highly levered firms likely incur agency costs of debt and financial distress costs (Jensen \& Meckling, 1976; Myers, 1977). We measure leverage using the ratio of total debt to total assets $(L E V)$. Research and development expenditures are typically expensed and not capitalized but they may create value (Servaes \& Tamayo, 2013). We calculate 
the ratio of research and development expenses to total sales $(\mathrm{R} \& \mathrm{D} / \mathrm{S})$, where missing research and development expenses are set to zero. Growing firms have higher valuations (Klapper \& Love, 2004). We measure growth opportunities using sales growth, defined as the change in sales from the previous year $(S G R)$. Firms located in economically developed countries may have higher valuations (Griffin, Guedhami, Kwok, Li, \& Shao, 2015). We measure economic development using the natural logarithm of GDP per capita each year evaluated in 2000 US\$ $\left(L O G_{-} G D P\right)$.

To mitigate concerns about reverse causality and simultaneity bias, we lag the right-handside variables by one period. ${ }^{15}$ To address concerns about endogeneity stemming from omitted variables correlated with CSR and firm value, we follow Servaes and Tamayo (2013) and include firm fixed effects. ${ }^{16,17}$ Equation (1) also includes year fixed effects. To address crosssectional dependence and time-series correlation in our panel data set we report robust standard errors adjusted for clustering by firm.

In Hypotheses 2 through 7 we separately consider different channels through which CSR can help firms overcome institutional voids and thereby increase value. These channels include improved access to financing and excess growth through external financing in countries with weak equity and credit market efficiency, increased investment and lower default risk in countries with limited business freedom, and lower payable turnover (i.e., longer trade credit period) and higher future sales growth in countries with weak legal institutions. To examine how the strength of a country's market-supporting institutions affect the relation between CSR and these channels, we replace the dependent variable, $T O B Q$, in equation (1) with seven firm-level outcomes (channels). As discussed above, we capture access to equity markets using a dummy for equity issuance (Equity Issue), access to debt markets using a dummy for debt issuance (Debt 
Issue), and the value generated from accessing external financial (equity and debt) markets using externally financed growth (Excess Growth). We capture investment intensity using the ratio of capital expenditures to lagged property, plant, and equipment (Investment) and the probability of default using the probability of bankruptcy derived from the Black-Scholes-Merton model (Bankruptcy). Finally, we measure payable turnover using the ratio of cost of goods sold to accounts payable (Payable Turnover) and future sales growth using sales growth over the next two years (Sales Growth). More specifically, we estimate the following regression model:

$$
\begin{aligned}
\text { Channel }_{i t}= & \beta_{0}+\beta_{1} \text { CSR_P }_{i t-1}+\beta_{2} \text { Institution }_{i t-1}+\beta_{3} \text { CSR }_{-} P_{i t-1} \times \text { Institution }_{i t-1} \\
& +\sum_{k=1}^{6} \delta_{k} \text { CONTROL }_{k i t-1}+\mu_{i}+\mu_{t}+\varepsilon_{i t}
\end{aligned}
$$

\section{EMPIRICAL RESULTS}

\section{The Relation between CSR and Firm Value: The Role of Market-Supporting Institutions}

Table 3 reports the results of testing Hypothesis 1. We find that the coefficient on CSR_P is positive and statistically significant across all models. This evidence, based on regressions that control for various dimensions of the institutional environment as well as firm fixed effects, suggests that CSR is value-increasing, consistent with strategic stakeholder management. Moreover, the institutional indices load positively and are significant at conventional levels across all models, suggesting that strong market-supporting institutions also contribute to corporate value. More importantly for our purposes, the relation between CSR and firm value is weaker (stronger) in countries with stronger (weaker) market-supporting institutions. Specifically, the coefficients on the interactions between $C S R_{-} P$ and the institutional indices capturing stock and credit market efficiency, the extent of business freedom, and legal system efficiency and property rights are all negative and statistically significant, in line with our 
prediction. ${ }^{18}$ The coefficients on the control variables are generally consistent with those in earlier studies. In particular, larger and more established firms are associated with lower Tobin's q, better performing firms have higher Tobin's q, and firms with greater leverage have lower Tobin's q.

\section{Table 3 about here}

Based on the results in Table 3, we can determine the economic significance of the effect of market-supporting institutions on the relation between CSR and firm value. Specifically, one can calculate the impact of a one-standard-deviation increase in $C S R_{-} P$ on $T O B Q$ for different levels of institutional strength. When Stock Market Efficiency is set to its first quartile value (4.93), a one-standard-deviation increase in $C S R_{-} P(0.29)$ is associated with an increase in $T O B Q$ of $(0.753-0.105 \times 4.93) \times 0.29=0.07$. In contrast, when Stock Market Efficiency is set to its third quartile value (6.92), a one-standard-deviation increase in $C S R_{-} P(0.29)$ is associated with an increase in $T O B Q$ of $(0.753-0.105 \times 6.92) \times 0.29=0.01$. The difference of 0.06 is not trivial given that the mean (median) $T O B Q$ is $1.76(1.43)$. The corresponding differences for the other institutional indices are: 0.06 for Credit Market Efficiency, 0.04 for Business Freedom, and 0.09 for Legal System \& Property Rights. Appendix C provides details on how we calculate the economic significance of the effect of market-supporting institutions on the relation between CSR and firm value.

\section{Channels}

Table 4 reports the results of testing Hypotheses 2 through 7. In columns (1) through (4), we find that the coefficients on the interactions between our proxies for the strength of capital market efficiency and $C S R_{-} P$ are negative and significant, implying that the impact of CSR performance on new equity and debt issuance as well as externally financed growth is higher in 
countries with weaker capital markets. These results are in line with Hypotheses 2 and 3, and suggest that CSR activities help firms overcome weak stock and credit markets by allowing them to access external financing and achieve higher growth than possible if they were to rely only on internally generated capital.

\section{Table 4 about here}

In column (5) (column (6)), we find that the coefficients on the interactions between our proxies for business freedom and CSR_P are negative (positive) and significant, implying that the impact of CSR performance on investment intensity (probability of bankruptcy) is higher (lower) in countries with limited business freedom. These results support Hypotheses 4 and 5, and suggest that CSR initiatives help firms overcome voids in regulatory institutions by allowing them to make positive NPV investments, thus increasing their chance of survival.

In column (7) (column (8)), we find that the coefficients on the interaction between our proxy for legal system efficiency and $C S R_{-} P$ is positive (negative) and significant, indicating that the effect of CSR performance on payable turnover (future sales growth) is lower (higher) in countries with weaker legal institutions and limited property rights. These results support Hypotheses 6 and 7, and suggest that firms with high CSR scores have a positive reputation with suppliers and customers that allows them to obtain better credit terms and higher future sales growth.

Taken together, the results in Tables 3 and 4 suggest that firms that actively engage in CSR activities can reduce transaction costs, improve access to resources, and enhance competitive advantages in countries with weak or absent market-supporting institutions and therefore achieve a higher valuation. 


\section{ROBUSTNESS TESTS}

In this section, we address concerns about potential endogeneity influencing our results. For parsimony, we focus on the relation between CSR and Tobin's q, as it summarizes the valuation effect of CSR operating through various channels. In addition, the relation between CSR and Tobin's q applies to the various institutions we examine, unlike various firm-level outcomes (channels), which apply only to a subset of market institutions.

\section{Heckman Sample Selection Test}

One concern is that our sample may not be random. In particular, one might argue that successful firms in weak institutional environments with higher CSR performance drive our results, with ASSET4 overlooking firms in weak institutional environments with lower CSR performance. That is, one might be concerned that our analyses suffer from sample selection bias. To address this concern, we merge the ASSET4 sample with the Compustat North America and Compustat Global universe, and distinguish firms with CSR scores (i.e., covered in ASSET4) from firms without CSR scores (i.e., not covered in ASSET4). We then perform a Heckman-type correction. To do so, we create a dummy variable equal to 1 if the firm is covered in ASSET4, and 0 otherwise. We then estimate a Probit model with this dummy as a dependent variable and firm characteristics (SIZE, ROA, $L E V, R \& D / S$, and $S G R$ ) as well as country characteristics (LOG_GDP, Stock Market Efficiency, Credit Market Efficiency, Business Freedom, and Legal System \& Property Rights) as independent variables. We also include year and industry effects. Using the predicted values from this Probit estimation, we obtain the inverse Mills ratio ( $L A M B D A)$, which we include as an additional control in equation (1). The inverse Mills ratio controls for selection bias. Untabulated results show that the coefficients on the interaction terms between CSR performance and the institutional indices are negative and 
statistically significant, confirming the results in Table 3. Additional documentation and results from this analysis are available in the online appendix.

\section{Propensity Score Matching}

A firm's decision to increase its CSR performance depends on the costs and benefits of CSR investment, which are determined in part by firm characteristics. Therefore, one might be concerned that firm characteristics rather than CSR drive the result that socially responsible firms are associated with higher valuations in countries with weaker market-supporting institutions. To address this concern, we randomize our sample by employing the propensity score matching method developed by Rosenbaum and Rubin (1983). We first construct a dummy variable indicating whether $C S R_{-} P$ is higher than the country median, $C S R \_P \_H I$. We then regress this indicator variable on firm- $(S I Z E, R O A, L E V, R \& D / S, S G R)$ and country-level $\left(L O G_{-} G D P\right)$ variables to obtain the predicted probability (propensity score) from the Probit regression model. Next, we match each observation from the treatment group (i.e., $C S R \_P \_H I=1$ ) to an observation in the control group (i.e., $C S R_{-} P_{-} H I=0$ ) with the closest propensity score. ${ }^{19}$ Using the matched sample, we continue to find that the coefficient on the interaction between $C S R \_P$ and the proxies for market-supporting institutions are negative and statistically significant across all models. Therefore, our results are robust to matching on the determinants of CSR performance, suggesting that firm characteristics do not drive our results. ${ }^{20}$ Additional documentation and results from this analysis are available in the online appendix.

\section{Excluding Cross-Listed Firms}

Firms cross-listed on major stock exchanges have access to resources in countries in which the stock exchanges are located and therefore are less likely to be affected by weak market-supporting institutions at home. Thus, inclusion of cross-listed firms in our sample works 
against finding a relation between country-level market-supporting institutions and the CSRvaluation link. However, if cross-listed firms are more likely to be located in developed countries and such firms invest in CSR and have higher values, inclusion of cross-listed firms in the sample might influence our results. To rule out this possibility, we re-estimate our regressions after excluding firms cross-listed on major U.S. stock exchanges using the Securities and Exchange Commission's Central Index Key information in Compustat Global. Firms cross-listed in the U.S. represent roughly $20 \%$ of our sample firm-years. Untabulated tests show that all of our results are robust to excluding these cross-listed firms from the sample. The results from this analysis are available in the online appendix.

\section{DISCUSSION AND CONCLUSION}

\section{Summary and Contributions to the Literature}

Building on transaction cost theories and the resource-based view of a firm, we develop a theoretical framework that predicts greater strategic value of CSR in countries with weaker market-supporting institutions. The absence of market-supporting institutions results in higher transaction costs and limited access to resources. We argue that CSR helps reduce transaction costs and facilitates access to resources, thereby improving competitive advantage of firms operating in countries with institutional voids. Using a sample of 2,445 firms from 53 countries over the period 2003-2010 and controlling for firm-level unobservable heterogeneity, we find supportive evidence that CSR is more positively related to firm value in countries with weaker market institutions. In particular, we find that CSR is associated with improved access to financing in countries with weaker equity and credit markets, greater investment and lower default risk in countries with more limited business freedom, and lower payable turnover and 
higher future sales growth in countries with weaker legal institutions and more limited property rights.

Endogeneity is a concern in international business research because a randomized controlled experiment is not feasible (Reeb, Sakakibara, \& Mahmood, 2012). Endogeneity has also been recognized as a concern for studies that examine the relation between CSR and financial performance (McWilliams \& Siegel, 2000; Rodriguez et al., 2006). Following Reeb et al.'s (2012) suggestion, we apply several research design choices (e.g., firm fixed effects, propensity score matching, and instrumental variables approaches) that approximate randomization.

The fixed effects design is a generalization of the difference-in-differences approach (Imai \& Kim, 2014) and is well suited for analyses with panel data. One caveat of firm-fixed effect models is the possibility of fixed effects removing the theoretical, cross-sectional variation of interest when firm characteristics change slowly over time (Zhou, 2001). While it may be difficult to interpret a lack of evidence from fixed effects, evidence of causal relation in firm-fixed effect models can be quite compelling (Reeb et al., 2012). We base all our analyses on firm-fixed effect models and obtain results consistent with our hypotheses.

Matching approximates a randomized-controlled experiment by eliminating firms from either the treatment or control group that do not share similar characteristics (Angrist \& Pischke, 2008). Propensity score matching allows a refined matching process along multiple firm characteristics (Dehejia \& Wahba, 1999). The instrumental variables approach deals with endogeneity by seeking an exogenous proxy for the treatment (Lacker \& Rusticus, 2010). Our 
results are robust to propensity score matching based on the determinants of CSR and to instrumental variables approach using industry-year average CSR as an instrumental variable.

Our study makes several important contributions to international business research. Most importantly, we add to the literature on institutional voids by providing new theoretical and empirical insights. While prior studies focus primarily on market responses to institutional voids, such as business groups and strategic alliances (Fisman \& Khanna, 2004; Khanna \& Palepu, 2000a; Leff, 1978; Peng et al., 2005; Siegel, 2009), we develop a theoretical framework that explains the role of CSR in filling institutional voids. Based on transaction cost theories and the resource-based view of a firm, we posit that CSR improves a firm's competitive advantages by reducing transaction costs, thereby facilitating access to resources when market-supporting institutions are weak. Our empirical results are consistent with this prediction. $^{21}$

Our study also contributes to recent literature on the factors mediating the relation between CSR and firm value (Luo at al., 2015; Servaes \& Tamayo, 2013; Surroca, Tribo, \& Waddock, 2010; Wang \& Bansal, 2012). Our results suggest that the country-level institutional environment affects the link between CSR and firm value. In particular, the more positive relation between CSR and firm value in countries with weaker market-supporting institutions suggests that the strategic value of CSR is greater where institutional voids lead to higher transaction costs.

Finally, our study contributes to the literature on transaction costs. Traditional transaction cost research focuses on micro-analytical aspects such as opportunism and bounded rationality (Meyer et al., 2009), while the role of macro-level factors such as country-level regulatory institutions remains largely unexplored. In an initial attempt to fill this gap in the literature, 
Meyer et al. (2009) examine the impact of market-supporting institutions on business strategies by analyzing the entry strategy of foreign investors in emerging markets. We extend this line of research by showing that a non-market strategy (e.g., CSR) can help reduce transaction costs when market-supporting institutions are absent or weak.

\section{Limitations and Directions for Future Research}

Our study responds to a call for interdisciplinary research on the role of market and nonmarket strategies in addressing institutional voids. Our results on the role of CSR in filling institutional voids should be interpreted with the following limitations in mind. First, while firm fixed effects and the instrumental variables approach are designed to address endogeneity between CSR and firm value, unobserved factors that shape the strength of country-level institutions may also affect the relation between CSR and firm value. Ideally, we would examine whether that relation changes after exogenous shocks to market-supporting institutions induced by regulatory changes. Unfortunately, identifying such a natural experimental setting is known to be difficult. Future studies may leverage an exogenous shock in one country or multiple countries to re-examine our predictions. Second, while we focus on how market-supporting institutions influence the relation between CSR and firm value, other types of institutions or national culture may also affect the strategic value of CSR. Future research might examine the effect of alternative macro-level factors on the strategic value of CSR. Third, while we focus on CSR as a non-market strategy to help address market failures associated with institutional voids, other types of non-market mechanisms, such as ethnic identity, religion, or culture, can also reduce transaction costs and help access resources when market-supporting institutions are absent or weak. Research examining the role of various non-market mechanisms would improve our understanding of how firms can fill institutional voids in emerging economies. 


\section{ENDNOTES}

${ }^{1}$ While prior literature tends to associate institutional voids with emerging markets, the quality of developed markets' institutions also varies (e.g., Khanna \& Palepu, 2010).

${ }^{2}$ Our theoretical framework is consistent with Khanna, Palepu, \& Bullock (2010), who argue that "a prospective emerging giant can build confidence and social capital in consumer, supplier and investor circles, contributing to its competitive advantage." The authors offer a few examples of firms that have employed CSR to fill institutional voids. For instance, Zain — a telecom provider —introduced One Network in Sub-Saharan Africa, which effectively eliminated roaming charges in this market. This strategy was specifically designed to make telecommunications accessible to poor customers. Zain also invested heavily in Africa, creating direct and indirect employment and quickly becoming the largest taxpayer in many countries in which it operated. The positive image of "partner in progress" smoothed Zain's government relations and helped it become the world's fastest growing telecom provider by 2008.

${ }^{3}$ We thank an anonymous reviewer for suggesting this theoretical framework.

${ }^{4}$ Jones and Hill (1988) suggest bounded rationality, opportunism, uncertainty and complexity, a low number of trading relationships, information asymmetry, and asset specificity as six main factors leading to transaction difficulties.

${ }^{5}$ Other studies report no relation (McWilliams \& Siegel, 2000) or a negative relation (Wright \& Ferris, 1997). Recent meta-analyses (e.g., Margolis, Elfenbein, \& Walsh, 2007; Orlitzky, Schmidt, \& Rynes, 2003) note that this line of research generally finds a positive relation between CSR and corporate financial performance, particularly in recent years. However, the direction of causality remains largely unresolved.

${ }^{6}$ Corporations engage in socially responsible activities for a variety of reasons; some are strategic and others are altruistic (Baron, 2001; Hillman \& Keim, 2001). Young and Makhija (2014) provide a thorough discussion and integration of CSR theories. While firms may invest in CSR for altruistic reasons in countries with strong institutions, the strategic value of CSR in reducing transaction costs in emerging 
economies suggests that the strategic value of CSR is greater in countries with weaker market-supporting institutions than in countries with stronger institutions.

${ }^{7}$ In the international business context, Strike, Gao, and Bansal (2006) assess whether international diversification affects the propensity of firms to be socially responsible or irresponsible. Husted and Allen (2006) assess the relation between multinational enterprises' global or country-specific CSR and their international organizational strategy. Luo (2006) examines the relation between CSR and the political strategy of multinational enterprises. Christmann and Taylor (2006) find that a firm shapes its CSR strategy in response to customer preference, monitoring, and expected sanctions, and Waldman, Siegel, and Javidan (2006) show that country-specific cultural factors and CEO leadership characteristics are associated with the values that top management team members attach to CSR.

${ }^{8}$ See http://im.thomsonreuters.com/solutions/content/asset4-esg/.

${ }^{9}$ We obtain qualitatively similar results when we use CSR ratings from Governance Metrics International as an alternative proxy for CSR.

${ }^{10}$ To ensure our results are not driven by a few countries, we re-run our regressions after excluding countries with fewer than 10 observations (15 countries) and fewer than 100 observations (35 countries). We further estimate weighted regressions where weights are given by the inverse of the number of observations per country. Untabulated results are consistent with those reported, suggesting that our results are not driven by heterogeneity in the number of observations across countries.

${ }^{11}$ All of our inferences are qualitatively similar when we examine the environmental performance and social performance scores separately.

${ }^{12}$ For example, Khanna, Palepu, and Sinha (2005) examine institutional voids in terms of political and social systems, openness to foreign investment, and quality of product, labor, and capital markets. Meyer et al. (2009) and Gubbi, Aulakh, Ray, Sarkar, and Chittoor (2010) focus on the areas of business freedom, trade freedom, property rights, investment freedom, and financial freedom. Chakrabarty (2009) captures institutional voids along two dimensions: financial credit availability and agency contracting. 
${ }^{13}$ These databases have the advantage of consistently providing a time series of relevant institutional variables for a large number of countries.

${ }^{14}$ With respect to legal institutions, Gwartney, Hall, and Lawson (2014: 5) argue that "perhaps more than any other area, this area is essential for the efficient allocation of resources. Countries with major deficiencies in this area are unlikely to prosper regardless of their policies in the other four areas."

${ }^{15}$ We also check potential reverse causality between CSR and firm value through the Granger causality test. Specifically, we regress $T O B Q$ and $C S R_{-} P$ on lagged $T O B Q$, lagged $C S R \_P$, the vector of other controls (SIZE, ROA, $L E V, R \& D / S, S G R$, and $\left.L O G_{-} G D P\right)$, as well as year and firm fixed effects. In an alternative specification, we add an additional lag of TOBQ and CSR_P. Untabulated results show that $T O B Q$ does not Granger-cause $C S R_{-} P$, suggesting that reverse causality is not a significant concern in our study.

${ }^{16}$ Servaes and Tamayo (2013) argue that mixed findings in the literature on the link between CSR and firm value are due in part to model misspecification arising from the omission of controls for timeinvariant unobservable firm characteristics. A Hausman test rejects firm random effects in favor of firm fixed effects. The fixed effects design is a generalization of the difference-in-differences approach (Imai \& Kim, 2014).

${ }^{17}$ If firm CSR policies are sticky, i.e., change little over time, the relation between CSR and firm value is driven by cross-sectional rather than time series variation in CSR. Zhou (2001) shows that in such a case, firm fixed effects may absorb the effect of CSR on firm value, leaving CSR with no significant explanatory power in firm value regressions. In other words, we might fail to detect a relation between CSR and firm value even if one truly exists. To explore this issue, we calculate between (cross-sectional) and within (timeseries) variation in CSR. For the between variation, we calculate the standard deviation of CSR by year across firms. The average of these standard deviations is 0.28 . For the within variation, we calculate standard deviation of CSR by firm across years. The average of these standard deviations is 0.11 . Although 
between variation in CSR is larger than within variation, there is still relatively enough within variation in CSR to detect the effect of CSR on firm value in the presence of firm fixed effects.

${ }^{18} \mathrm{We}$ also estimate the model in equation (1) using an overall measure of the strength of marketsupporting institutions, calculated by aggregating the stock market efficiency, credit market efficiency, the extent of business freedom, and legal system efficiency indices. The untabulated results are consistent with those in Table 3 . That is, the coefficient on CSR is positive and statistically significant at the $1 \%$ level, and the coefficient on the interaction between CSR and the overall strength of market-supporting institutions is negative and statistically significant at the $1 \%$ level.

${ }^{19}$ We match with replacement. That is, a firm in the control group could be used as a match more than once.

${ }^{20} \mathrm{We}$ also implement instrumental variables estimation using the industry-year average CSR score excluding the focal firm (El Ghoul et al., 2011; Kim, Li, \& Li, 2014). The results, which are available in the online appendix, are qualitatively the same as those in Table 3.

${ }^{21}$ Our results are consistent with the economics-based profit-maximization view of CSR, coined as profitmaximizing ethics (Windsor, 2001) or strategic CSR (Baron, 2001) in the literature. That is, socially responsible actions can have a positive impact on a firm's cash flows, which is in line with the instrumental stakeholder theory in Jones (1995). 


\section{REFERENCES}

Adler, P. S., \& Kwon, S. W. 2002. Social capital: Prospects for a new concept. Academy of Management Review, 27(1): 17-40.

Akerlof, K. 1970. The market for 'lemons': Qualitative uncertainty and the market mechanism. Quarterly Journal of Economics, 84(3): 448-500.

Angrist, J., \& Pischke, J. 2008. Mostly harmless econometrics: An empiricist's companion. Princeton, NJ: Princeton University Press.

Barney, J. 1991. Firm resources and sustained competitive advantage. Journal of Management, 17(1), 99-120.

Baron, D. P. 2001. Private politics, corporate social responsibility and integrated strategy. Journal of Economics and Management Strategy, 10(1): 7-45.

Belkaoui, A. 1976. The impact of the disclosure of the environmental effects of organizational behavior on the market. Financial Management, 7(2): 26-31.

Bénabou, R., \& Tirole, J. 2010. Individual and corporate social responsibility. Economica, 77(305): 1-19.

Bragdon Jr, J. H., \& Marlin, J. A. 1972. Is pollution profitable? Risk Management, 19(4): 9-18.

Brammer, S. J., \& Pavelin, S. 2006. Corporate reputation and social performance: The importance of fit. Journal of Management Studies, 43(3), 435-455.

Chakrabarty, S. 2009. The influence of national culture and institutional voids on family ownership of large firms: A country level empirical study. Journal of International Management, 15(1): 32-45.

Chang, S. J., \& Hong, J. 2000. Economic performance of group affiliated companies in Korea: Intragroup resource sharing and internal business transactions. Academy of Management Journal, 43(3): 429-448. 
Cheng, B., Ioannou, I., \& Serafeim, G. 2014. Corporate social responsibility and access to finance. Strategic Management Journal, 35(1): 1-23.

Christmann. P., \& Taylor. G. 2006. Firm self-regulation through international certifiable standards of symbolic versus substantive implementation. Journal of International Business Studies, 37(6): 863-878.

Claessens, S., Djankov, S., Fan, J., \& Lang, L. 2002. Disentangling the incentive and entrenchment effects of large shareholdings. Journal of Finance, 57(6): 2741-2771.

Clarkson, M. E. 1995. A stakeholder framework for analyzing and evaluating corporate social performance. Academy of Management Review, 20(1), 92-117.

Cleary, S. 1999. The relationship between firm investment and financial status. Journal of Finance, 54(2): 673-692.

Coase, R. H. 1937. The nature of the firm. Econometrica, 4(16): 386-405.

Coase, R. H. 1960. The problem of social cost. Journal of Law and Economics, 3(1): 1-44.

Dehejia, R., \& Wahba, S. 1999. Causal effects in non-experimental studies: Re-evaluating the evaluation of training programs. Journal of the American Statistical Association, 94(448): 1053-1062.

Demirgüç-Kunt, A., \& Maksimovic, V. 2002. Funding growth in bank-based and market-based financial systems: Evidence from firm-level data. Journal of Financial Economics, 65(3): 337-363.

Dhaliwal, D. S., Li, O. Z., Tsang, A., \& Yang, Y. G. 2011. Voluntary nonfinancial disclosure and the cost of equity capital: The initiation of corporate social responsibility reporting. The Accounting Review, 86(1): 59-100. 
Doh, J. P., Lawton, T. C., \& Rajwani, T. 2012. Advancing nonmarket strategy research: Institutional perspectives in a changing world. Academy of Management Perspectives, 26(3): 22-39.

Du, S., Bhattacharya, C. B., \& Sen, S. 2011. Corporate social responsibility and competitive advantage: Overcoming the trust barrier. Management Science 57(9): 1528-1545.

Durnev, A, \& Kim, E. H. 2005. To steal or not to steal: Firm attributes, legal environment, and valuation. Journal of Finance, 60(3): 1461-1493.

El Ghoul, S., Guedhami, O., Kwok, C. C., \& Mishra, D. R. 2011. Does corporate social responsibility affect the cost of capital? Journal of Banking \& Finance, 35: 2388-2406.

Fama, E. F., \& French, K. R. 1997. Industry costs of equity. Journal of Financial Economics, 43(2): 153-194.

Fisman, R., \& Khanna, T. 2004. Facilitating development: The role of business groups. World Development, 32(4): 609-628.

Flammer, C. 2015. Does corporate social responsibility lead to superior financial performance? A regression discontinuity approach. Management Science, 61(11): 2549-2568.

Foss, K., \& Foss, N. J. 2005. Resources and transaction costs: How property rights economics furthers the resource-based view. Strategic Management Journal, 26(6), 541-553.

Freedman, M., \& Stagliano, A. J. 1991. Differences in social-cost disclosures: A market test of investor reactions. Accounting, Auditing \& Accountability Journal, 4(1): 68-83.

Friedman, M. 1962. Capitalism and freedom. Chicago, IL: University of Chicago Press.

Friedman, M. 1970. The social responsibility of business is to increase its profits. New York Times, September 13: 122-126.

Gelb, D. S., \& Strawser, J. A. 2001. Corporate social responsibility and financial disclosures: An alternative explanation for increased disclosure. Journal of Business Ethics, 33(1): 1-13. 
Godfrey P. C. 2005. The relationship between corporate philanthropy and shareholder wealth: A risk management perspective. Academy of Management Review, 30(4): 777-798.

Griffin, D., Guedhami, O., Kwok, C .C. Y., Li, K., \& Shao, L. 2015. National culture, corporate governance practices, and firm performance. Working paper, University of South Carolina.

Gubbi, S. R., Aulakh, P. S., Ray, S., Sarkar, M. B., \& Chittoor, R. 2010. Do international acquisitions by emerging-economy firms create shareholder value? The case of Indian firms. Journal of International Business Studies, 41(3): 397-418.

Gwartney, J. D., Hall, J. C., \& Lawson, R. 2014. Economic freedom of the world: 2014 annual report. Vancouver, BC: Fraser Institute.

Hart, S. L. 1995. A natural-resource-based view of the firm. Academy of Management Review, 20(4), 986-1014.

Hill, C. W., \& Jones, G. R. 1989. Strategic management: An integrated approach. Boston, MA: Houghton Mifflin.

Hillegeist, S. A., Keating, E. K., Cram, D. P., \& Lundstedt, K. G. 2004. Assessing the probability of bankruptcy. Review of Accounting Studies, 9(1): 5-34.

Hillman, A., and Keim, G. 2001. Shareholder value, stakeholder management, and social issues: What's the bottom line? Strategic Management Journal, 22(2): 125-139.

Husted, B. W., \& Allen, D. B. 2006. Corporate social responsibility in the multinational enterprises: Strategic and institutional approaches. Journal of International Business Studies, 37(6): 838-849.

Imai, K., \& Kim, I. S. 2014. On the use of linear fixed effects regression estimators for causal inference. Working paper, Princeton University. 
Ioannou, I., \& Serafeim, G. 2012. What drives corporate social performance? The role of nationlevel institutions. Journal of International Business Studies, 43(9): 834-864.

Jayachandran, S., Kalaignanam, K., \& Eilert, M. 2013. Product and environmental social performance: Varying effect on firm performance. Strategic Management Journal, 34(10): $1255-1264$.

Jensen, M.C., \& Meckling, W.H. 1976. Theory of the firm: Managerial behavior, agency costs and ownership structure. Journal of Financial Economics, 3(3): 305-360.

Jones, T. M. 1995. Instrumental stakeholder theory: A synthesis of ethics and economics. Academy of Management Review, 20(2), 404-437.

Jones, G. R., \& Hill, C. W. L. 1988. Transaction cost analysis of strategy-structure choice. Strategic Management Journal, 9(2): 159-172.

Karna, A., Täube, F., \& Sonderegger, P. 2013. Evolution of innovation networks across geographical and organizational boundaries: A study of $\mathrm{R} \& \mathrm{D}$ subsidiaries in the Bangalore IT cluster. European Management Review, 10(4), 211-226.

Khanna, T., \& Palepu, K. G. 1997. Why focused strategies may be wrong for emerging markets. Harvard Business Review, 75(4): 41-51.

Khanna, T., \& Palepu, K. G. 2000a. The future of business groups in emerging markets: Longrun evidence from Chile. Academy of Management Journal, 43(3): 268-285.

Khanna, T., \& Palepu, K. 2000b. Emerging market business groups, foreign investors and corporate governance. In R. Morck (Ed.), Concentrated ownership: 265-294. Chicago: University of Chicago Press.

Khanna, T., \& Palepu, K. G. 2000c. Is group affiliation profitable in emerging markets? An analysis of diversified Indian business groups. Journal of Finance, 55(2): 867-891. 
Khanna, T., \& Palepu, K. G. 2010. Winning in emerging markets: A road map for strategy and execution. Boston: Harvard Business Press.

Khanna, T., \& Palepu, K. G. 2011. Winning in emerging markets: Spotting and responding to institutional voids. World Financial Review, May-June: 18-20.

Khanna, T., Palepu, K. G., \& Bullock, R. 2010. Winning in emerging markets: A road map for strategy and execution. Harvard Business Press.

Khanna, T., Palepu, K. G., \& Sinha, J. 2005. Strategies that fit emerging markets. Harvard Business Review, 83(6): 4-19.

Kim, Y., Li, H., \& Li, S. 2014. Corporate social responsibility and stock price crash risk. Journal of Banking \& Finance, 43: 1-13.

Kim, Y., Park, M. S., \& Wier, B. 2012. Is earnings quality associated with corporate social responsibility? The Accounting Review, 87(3): 761-796.

Klapper, L. F., \& Love, I. 2004. Corporate governance, investor protection, and performance in emerging markets. Journal of Corporate Finance, 10(5): 703-728.

Klein, B., Crawford, R. G., \& Alchian, A. A. 1978. Vertical integration, appropriable rents, and the competitive contracting process. Journal of Law and Economics, 21(2): 297-326.

Kuppuswamy, V., Serafeim, G., \& Villalonga, B. 2012. The effect of institutional factors on the value of corporate diversification. Harvard Business School Accounting and Management Unit Working Paper No. 13-022, available at SSRN: http://ssrn.com/abstract=2132676.

La Porta, R., Lopez-de-Silanes, F., \& Shleifer, A. 1999. Corporate ownership around the world. Journal of Finance, 54(2): 471-517.

La Porta, R., Lopez-de-Silanes, F., Shleifer, A., \& Vishny, R. 1998. Law and finance. Journal of Political Economy, 106(6): 1113-1155. 
Leff, N. 1978. Industrial organization and entrepreneurship in the developing countries: The economic groups. Economic Development and Cultural Change, 26(4): 661-675.

Lev, B., Petrovits, C., \& Radhakrishnan, S. 2010. Is doing good good for you? How corporate charitable contributions enhance revenue growth. Strategic Management Journal, 31(2): $182-200$.

Luo, X., Wang, H., Raithel, S., \& Zheng, Q. 2015. Corporate social performance, analyst stock recommendations, and firm future returns. Strategic Management Journal, 36(1): 123-136.

Luo, Y. 2006. Political behavior, social responsibility, and perceived corruption: A structuration perspective. Journal of International Business Studies, 37(6): 747-766.

Luo, Y., \& Tung, R. L. 2007. International expansion of emerging market enterprises: A springboard perspective. Journal of International Business Studies, 38(4), 481-498.

Margolis, J. D., Elfenbein, H. A., \& Walsh, J. P. 2007. Does it pay to be good? A meta-analysis and redirection of research on the relationship between corporate social and financial performance. Working paper, Harvard Business School.

McLean, R. D., Zhang, T., \& Zhao, M. 2012. Why does the law matter? Investor protection and its effects on investment, finance, and growth. Journal of Finance, 67(1): 313-350.

McWilliams, A., \& Siegel, D. 2000. Corporate social responsibility and financial performance: Correlation or misspecification. Strategic Management Journal, 21(5): 603-609.

McWilliams, A., \& Siegel, D. 2001. Corporate social responsibility: A theory of the firm perspective. Academy of Management Review, 26(1): 117-127.

Meyer, K. E., Estrin, S., Bhaumik, S. K., \& Peng, M. W. 2009. Institutions, resources, and entry strategies in emerging economies. Strategic Management Journal, 30(1): 61-80. 
Meyer, J. W., \& Rowan, B. 1977. Institutionalized organizations: Formal structure as myth and ceremony. American Journal of Sociology, 83(2): 340-363.

Miller, D., Lee, J., Chang, S., \& Le Breton-Miller, I. 2009. Filling the institutional void: The social behavior and performance of family vs non-family technology firms in emerging markets. Journal of International Business Studies, 40(5), 802-817.

Morck, R., Shleifer, A., \& Vishny, R. W. 1988. Management ownership and market valuation: An empirical analysis. Journal of Financial Economics, 20(1-2): 293-315.

Myers, S. C. 1977. Determinants of corporate borrowing. Journal of Financial Economics, 5(2): 147-175.

Nahapiet, J., \& Ghoshal, S. 1998. Social capital, intellectual capital, and the organizational advantage. Academy of Management Review, 23(2), 242-266.

Oliver, C. 1991. Strategic responses to institutional processes. Academy of Management Review, $16(1), 145-179$.

Orlitzky, M., Schmidt, F., \& Rynes, S. 2003. Corporate social and financial performance: A meta-analysis. Organization Studies, 24(3): 403-441.

Pava, M. L., \& Krausz, J. 1996. The association between corporate social responsibility and financial performance: The paradox of social cost. Journal of Business Ethics, 15(3): 321357.

Peng, M. W., Lee, S. H., \& Wang, D. 2005. What determines the scope of the firm over time? A focus on institutional relatedness. Academy of Management Review, 30(3): 622-633.

Penrose, E. T. 1995. The theory of the growth of the firm. Oxford University Press (original work published 1959). 
Porter, M. E. 1991. Towards a dynamic theory of strategy. Strategic Management Journal, 12(S2), 95-117.

Porter, M. E., \& Kramer, M. R. 2002. The competitive advantage of corporate philanthropy. Harvard Business Review, 80(12): 56-68.

Porter, M. E., \& Kramer, M. R. 2006. The link between competitive advantage and corporate social responsibility. Harvard Business Review, 84(12): 78-92.

Porter, M. E., \& Kramer, M. R. 2011. Creating shared value. Harvard Business Review, 89(1/2): $62-77$.

Reeb, D., Sakakibara, M., \& Mahmood, I. P., 2012. From the editors: Endogeneity in international business research. Journal of International Business Studies, 43(3): 211-218.

Reeve, T. 1990. The firm as a nexus of internal and external contracts. In M. Aoki, B. Gustafson, \& O. E. Williamson (Eds.), The firm as a nexus of treaties: 133-161. London: Sage.

Ricart , J. E., Enright, M. J., Ghemawat, P., Hart, S. L., \& Khanna, T. 2004. New frontiers in international strategy. Journal of International Business Studies, 35(3): 175-200.

Robins, J. A. 1992. Organizational considerations in the evaluation of capital assets: Toward a resource-based view of strategic investment by firms. Organization Science, 3(4): 522-536.

Rodriguez, P., Siegel, D. S., Hillman, A., \& Eden, L. 2006. Three lenses on the multinational enterprise: Politics, corruption, and corporate social responsibility. Journal of International Business Studies, 37(6): 733-746.

Rosenbaum, P., \& Rubin, D. 1983. The central role of the propensity score in observational studies for causal effects. Biometrika, 70(1): 41-55.

Russo, M. V., \& Fouts, P. A. 1997. A resource-based perspective on corporate environmental performance and profitability. Academy of Management Journal, 40(3), 534-559. 
Saxton, T. 1997. The effects of partner and relationship characteristics on alliance outcomes. Academy of Management Journal, 40(2), 443-461.

Servaes, H., \& Tamayo, A. 2013. The impact of corporate social responsibility on firm value: The role of customer awareness. Management Science, 59(5): 1045-1061.

Shane, P. B., \& Spicer, B. H. 1983. Market response to environmental information produced outside the firm. The Accounting Review, 58(3): 521-538.

Siegel, J. 2009. Is there a better commitment mechanism than cross-listings for emerging economy firms? Evidence from Mexico. Journal of International Business Studies, 40(7): $1171-1191$.

Spicer, B. H. 1978. Investors, corporate social performance and information disclosure: An empirical study. The Accounting Review, 53(1): 94-111.

Strike, V. M., Gao, J., \& Bansal, P. 2006. Being good while being bad: Social responsibility and the international diversification of US firms. Journal of International Business Studies, 37(6): 850-862.

Surroca, J., Tribo, J. A., \& Waddock, S. 2010. Corporate responsibility and financial performance: The role of intangible resources. Strategic Management Journal, 31(6): 463490.

Teece, D. J. 1982. Towards an economic theory of the multiproduct firm. Journal of Economic Behavior \& Organization, 3(1), 39-63.

Waddock, S., \& Graves, S. 1997. The corporate social performance financial performance link, Strategic Management Journal, 18(4): 303-319.

Waldman, D. A., Siegel, D., \& Javidan, M. 2006. Components of transformational leadership and corporate social responsibility. Journal of Management Studies, 43(8): 1703-1725. 
Wang, T., \& Bansal, P. 2012. Social responsibility in new ventures: Profiting from a long-term orientation. Strategic Management Journal, 33(10): 1135-1153.

Wernerfelt, B. 1984. A resource-based view of the firm. Strategic Management Journal, 5(2): 171-180.

Williamson, O. 1975. Markets and hierarchies. New York: Free Press.

Williamson, O. E. 1985. The economic institutions of capitalism. New York: Free Press.

Williamson, O. E. 1991. Comparative economic organization: The analysis of discrete structural alternatives. Administrative Science Quarterly, 36(2): 269-296.

Windsor, D. 2001. "Corporate social responsibility: A theory of the firm perspective": Some comments. Academy of Management Review, 26(4): 502-504.

Wood, D. J. 1991. Corporate social performance revisited. Academy of Management Review, 16(4): 691-718.

Wright, P., \& Ferris, S. 1997. Agency conflict and corporate strategy: The effect of divestment on corporate value. Strategic Management Journal, 18(1): 77-83.

Yao, D. A. 1988. Beyond the reach of the invisible hand: Impediments to economic activity, market failures, and profitability. Strategic Management Journal, 9(S1): 59-70.

Young, S.L., \& Makhija, M.V. 2014. Firms' corporate social responsibility behavior: An integration of institutional and profit maximization approaches. Journal of International Business Studies, 46(7): 670-698.

Zhang, M., Ma, L., Su, J., \& Zhang, W. 2014. Do suppliers applaud corporate social responsibility? Journal of Business Ethics, 121(4): 543-557.

Zhou, X. 2001. Understanding the determinants of managerial ownership and the link between ownership and performance: Comment. Journal of Financial Economics, 62(3): 559-571. 


\section{Appendix A. Variable definitions and data sources}

\begin{tabular}{|c|c|c|}
\hline Variable & Definition & Source \\
\hline$T O B Q$ & $\begin{array}{l}\text { Tobin's q measured as the ratio of the market value of assets to } \\
\text { the book value of assets, where the market value of assets is } \\
\text { total assets plus market capitalization minus book equity. }\end{array}$ & $\begin{array}{l}\text { Authors' calculations } \\
\text { based on Compustat data }\end{array}$ \\
\hline Equity Issue & $\begin{array}{l}\text { Indicator variable for firms issuing equity when the net amount } \\
\text { issued divided by lagged assets exceeds } 1 \% \text {. The net amount } \\
\text { issued is the change in book equity, plus the change in deferred } \\
\text { taxes, minus the change in retained earnings (McLean et al., } \\
\text { 2012). }\end{array}$ & As above \\
\hline Excess Growth & $\begin{array}{l}\text { Geometric average of externally financed growth rate over the } \\
\text { next two years. The externally financed growth rate is } \\
\text { measured as sales growth minus the maximum growth rate } \\
\text { that can be financed if a firm relies only on its internal } \\
\text { resources }[R O A /(1-R O A)] \text { (Demirgüç-Kunt \& Maksimovic, } \\
2002) \text {. }\end{array}$ & As above \\
\hline Debt Issue & $\begin{array}{l}\text { Indicator variable for firms issuing debt when the net amount } \\
\text { issued divided by lagged assets exceeds } 1 \% \text {. The net amount } \\
\text { issued is the change in total debt (McLean et al., 2012). }\end{array}$ & As above \\
\hline Investment & $\begin{array}{l}\text { Ratio of capital expenditures to lagged property, plant, and } \\
\text { equipment. }\end{array}$ & As above \\
\hline Bankruptcy & $\begin{array}{l}\text { The probability of bankruptcy based on the Black-Scholes- } \\
\text { Merton option-pricing model which values equity as a European } \\
\text { call option on the value of firm's assets. The value of equity, } V_{E} \text {, } \\
\text { could be obtained as } V_{E}=V_{A} e^{-\delta T} N\left(d_{1}\right)-X e^{-T} N\left(d_{2}\right)+ \\
\left(1-e^{-\delta T}\right) V_{A} \text {, where N(.) is the standard cumulative normal } \\
\text { distribution, } d_{1}=\left[\ln \left(V_{A} / X\right)+\left(r-\delta+\sigma_{A}^{2} / 2\right) T\right] / \sigma_{A} \sqrt{T}, d_{2}= \\
d_{1}-\sigma_{A} \sqrt{T}, V_{A} \text { is the value of assets, } \delta \text { is the dividend rate } \\
\text { measured as dividends to } V_{A}, X \text { is the face value of debt } \\
\text { measured as total liabilities, } T \text { is assumed equal to } 1 \text { year, } r \text { is } \\
\text { the risk-free rate measured as the yield on the } 1 \text {-year constant } \\
\text { maturity U.S. Treasury Securities and } \sigma_{A} \text { is the volatility of } \\
\text { asset returns. } V_{A} \text { and } \sigma_{A} \text { are estimated by solving the system of } \\
\text { equations comprising the equity value equation above and the } \\
\text { optimal hedge equation: } \sigma_{E}=\left[V_{A} e^{-\delta T} N\left(d_{1}\right) \sigma_{A}\right] / V_{E}, \text { where } \sigma_{E} \\
\text { is the volatility of equity returns computed over the previous } \\
\text { year. Equity returns are obtained from CRSP (for U.S. firms) } \\
\text { and Compustat Global (for non-U.S. firms). Then, firm's asset } \\
\text { returns could be obtained as } \mu=\max \left[\left(V_{A, t} / V_{A, t-1}\right)-1, r\right] . \\
\text { Finally, the probability of default is defined as } \\
N\left(\frac{-\ln \left(V_{A} / X\right)+\left(\mu-\delta-\left(\sigma_{A}^{2} / 2\right)\right) T}{\sigma_{A} \sqrt{T}}\right)\end{array}$ & As above \\
\hline Payable Turnover & Ratio of cost of goods sold to accounts payable. & As above \\
\hline Sales Growth & $\begin{array}{l}\text { Future sales growth measured as the geometric average growth } \\
\text { in sales over the next two years. }\end{array}$ & As above \\
\hline$C S R \_P$ & $\begin{array}{l}\text { The overall CSR performance is equal to the average of } \\
\text { environmental performance and social performance. } \\
\text { Environmental performance measures a firm's impact on living } \\
\text { and non-living natural systems, including the air, land, and } \\
\text { water, as well as complete ecosystems. Social performance } \\
\text { measures a firm's capacity to generate trust and loyalty with its } \\
\text { workforce, customers, and society, through its use of best } \\
\text { management practices. }\end{array}$ & ASSET4 \\
\hline
\end{tabular}




\begin{tabular}{|c|c|c|}
\hline SIZE & $\begin{array}{l}\text { Firm size is measured as the natural logarithm of total assets in } \\
\text { millions of \$US. }\end{array}$ & $\begin{array}{l}\text { Authors' calculations } \\
\text { based on Compustat data }\end{array}$ \\
\hline$R O A$ & $\begin{array}{l}\text { Return on assets measured as the ratio of net income before } \\
\text { extraordinary items to total assets. }\end{array}$ & As above \\
\hline$L E V$ & Leverage measured as the ratio of total debt to total assets. & As above \\
\hline$R \& D / S$ & $\begin{array}{l}\text { Ratio of research and development expenses to total sales. } \\
\text { Missing research and development expenses are set to zero. }\end{array}$ & As above \\
\hline SGR & $\begin{array}{l}\text { Sales growth measured as the change in sales from the previous } \\
\text { year. }\end{array}$ & As above \\
\hline$L O G \_G D P$ & $\begin{array}{l}\text { The natural logarithm of GDP per capita each year evaluation in } \\
\text { year } 2000 \text { \$US. }\end{array}$ & $\begin{array}{l}\text { Authors' calculations } \\
\text { based on World } \\
\text { Development Indicators } \\
\text { data }\end{array}$ \\
\hline $\begin{array}{l}\text { Stock Market } \\
\text { Efficiency }\end{array}$ & $\begin{array}{l}\text { Stock markets provide adequate financing to companies. } \\
\text { Obtained from an executive survey based on an index from } 0 \text { to } \\
10 \text {. }\end{array}$ & $\begin{array}{l}\text { IMD World } \\
\text { Competitiveness } \\
\text { Yearbook }\end{array}$ \\
\hline $\begin{array}{l}\text { Credit Market } \\
\text { Efficiency }\end{array}$ & $\begin{array}{l}\text { Credit is easily available for business. Obtained from an } \\
\text { executive survey based on an index of } 0 \text { to } 10 \text {. }\end{array}$ & As above \\
\hline Business Freedom & $\begin{array}{l}\text { An index of business regulations. Higher values of the index } \\
\text { imply fewer regulations. The subcomponents of the index are: } \\
\text { (1) Administrative requirements } \\
\text { (2) Bureaucracy costs } \\
\text { (3) Starting a business } \\
\text { (4) Extra payments/bribes/favoritism } \\
\text { (5) Licensing restrictions } \\
\text { (6) Cost of tax compliance }\end{array}$ & $\begin{array}{l}\text { Fraser Institute's } \\
\text { Economic Freedom of } \\
\text { the World }\end{array}$ \\
\hline $\begin{array}{l}\text { Legal System \& } \\
\text { Property Rights }\end{array}$ & $\begin{array}{l}\text { An index of the quality of the legal system and the security of } \\
\text { property rights. Higher values of the index imply better legal } \\
\text { systems and more secure property rights. The subcomponents of } \\
\text { the index are: } \\
\text { (1) Judicial independence } \\
\text { (2) Impartial courts } \\
\text { (3) Protection of property rights } \\
\text { (4) Military interference in rule of law and politics } \\
\text { (5) Integrity of the legal system } \\
\text { (6) Legal enforcement of contracts } \\
\text { (7) Regulatory restrictions on the sale of real property } \\
\text { (8) Reliability of police } \\
\text { (9) Business costs of crime }\end{array}$ & As above \\
\hline
\end{tabular}




\section{Appendix B. Market-supporting institutions by country}

\begin{tabular}{|c|c|c|c|c|}
\hline Country & $\begin{array}{l}\text { Stock market } \\
\text { efficiency }\end{array}$ & $\begin{array}{l}\text { Credit market } \\
\text { efficiency }\end{array}$ & $\begin{array}{l}\text { Business } \\
\text { freedom }\end{array}$ & $\begin{array}{l}\text { Legal system } \\
\& \\
\text { property rights }\end{array}$ \\
\hline Australia & 7.54 & 7.31 & 7.06 & 8.42 \\
\hline Austria & 5.87 & 6.64 & 6.91 & 8.54 \\
\hline Belgium & 6.12 & 6.23 & 6.74 & 7.26 \\
\hline Brazil & 4.98 & 4.14 & 3.91 & 4.84 \\
\hline Canada & 7.20 & 7.16 & 7.39 & 8.29 \\
\hline Chile & 6.59 & 6.77 & 6.77 & 7.20 \\
\hline China & 4.87 & 4.07 & 5.45 & 6.35 \\
\hline Colombia & 4.10 & 4.75 & 6.35 & 4.35 \\
\hline Czech Republic & 3.28 & 5.02 & 5.30 & 6.30 \\
\hline Denmark & 6.57 & 7.24 & 7.68 & 8.96 \\
\hline Egypt & & . & 5.90 & 5.30 \\
\hline Finland & 6.48 & 7.82 & 7.76 & 8.98 \\
\hline France & 5.95 & 5.63 & 6.84 & 7.47 \\
\hline Germany & 6.39 & 5.38 & 6.91 & 8.51 \\
\hline Greece & 5.03 & 5.57 & 6.05 & 6.05 \\
\hline Hong Kong & 8.11 & 7.79 & 7.90 & 8.07 \\
\hline Hungary & 3.10 & 3.05 & 6.05 & 6.35 \\
\hline India & 6.64 & 5.94 & 5.13 & 5.80 \\
\hline Indonesia & 5.40 & 5.02 & 5.95 & 4.60 \\
\hline Ireland & 5.65 & 6.45 & 7.30 & 8.01 \\
\hline Israel & 6.20 & 5.92 & 6.68 & 6.29 \\
\hline Italy & 4.15 & 4.35 & 5.86 & 5.89 \\
\hline Japan & 5.90 & 5.83 & 6.75 & 7.65 \\
\hline Kazakhstan & 3.90 & 4.25 & 6.10 & 5.70 \\
\hline Korea & 5.36 & 4.81 & 6.64 & 6.78 \\
\hline Kuwait & . & . & 6.60 & 7.15 \\
\hline Luxembourg & 5.94 & 6.85 & 7.11 & 8.40 \\
\hline Malaysia & 6.88 & 6.30 & 6.75 & 6.65 \\
\hline Mauritius & . & . & 7.10 & 6.23 \\
\hline Mexico & 3.74 & 3.01 & 5.65 & 4.68 \\
\hline Morocco & . & . & 6.35 & 6.00 \\
\hline Netherlands & 6.79 & 6.76 & 6.76 & 8.41 \\
\hline New Zealand & 5.70 & 7.01 & 7.73 & 8.63 \\
\hline Norway & 6.84 & 7.18 & 7.17 & 8.84 \\
\hline Panama & & . & 6.00 & 5.10 \\
\hline Papua New Guinea & . & . & 7.75 & 4.70 \\
\hline Peru & 4.23 & 5.13 & 5.95 & 5.10 \\
\hline Philippines & 4.96 & 5.28 & 5.75 & 4.50 \\
\hline Poland & 5.02 & 4.80 & 5.67 & 6.13 \\
\hline Portugal & 4.45 & 5.53 & 6.00 & 7.18 \\
\hline
\end{tabular}




\begin{tabular}{lcccc} 
Qatar & 5.29 & 6.81 & 8.50 & 7.50 \\
Russian Federation & 3.71 & 3.25 & 4.90 & 5.30 \\
Saudi Arabia &. &. & 8.20 & 7.70 \\
Singapore & 7.12 & 7.20 & 8.22 & 8.50 \\
South Africa & 6.85 & 5.06 & 6.40 & 5.55 \\
Spain & 5.64 & 5.48 & 6.23 & 6.69 \\
Sweden & 7.10 & 7.06 & 7.51 & 8.44 \\
Switzerland & 7.17 & 6.73 & 7.48 & 8.62 \\
Thailand & 6.02 & 6.21 & 6.30 & 5.63 \\
Turkey & 4.71 & 4.79 & 6.25 & 5.40 \\
United Arab & & & & 7.35 \\
Emirates &. & 5.85 & 7.00 & 8.22 \\
United Kingdom & 6.32 & 7.22 & 7.18 & 7.46 \\
United States & 7.38 & 6.04 & 6.74 & 7.29 \\
\hline All countries & 5.97 & & & \\
\hline
\end{tabular}




\section{Appendix C. Economic significance of market-supporting institutions by country}

We clarify how we obtain the economic significance of the impact of CSR on firm value in Table 3. Recall that our regression is as follows:

$$
\begin{gathered}
\text { TOB }_{i t}=\alpha_{0}+ \\
+\alpha_{1} \text { CSR_P }_{i t-1}+\alpha_{2} \text { Institution }_{i t-1}+\alpha_{3} \text { CSR_P }_{i t-1} \times \text { Institution }_{i t-1} \\
\\
+\sum_{k=1}^{6} \theta_{k} \text { CONTROL }_{k i t-1}+\mu_{i}+\mu_{t}+\varepsilon_{i t}
\end{gathered}
$$

To evaluate the marginal impact of $C S R \_P$ on $T O B Q$, we calculate the derivative of $T O B Q$ with respect to $C S R \_P$, which is given by:

$$
\frac{\partial T O B Q}{\partial C S R \_P}=\alpha_{1}+\alpha_{3} \text { Institution }
$$

We evaluate this derivative at the first quartile of Institution: $\alpha_{1}+\alpha_{3} \times \mathrm{Q} 1$ (Institution) and the third quartile of Institution: $\alpha_{1}+\alpha_{3} \times \mathrm{Q} 3$ (Institution)

Then we obtain the effect of one-standard-deviation increase in $C S R \_P(0.29)$ on $T O B Q$ evaluated at the first quartile of Institution: $\left[\alpha_{1}+\alpha_{3} \times \mathrm{Q} 1\right.$ (Institution) $] \times 0.29$ and the third quartile of Institution: $\left[\alpha_{1}+\alpha_{3} \times \mathrm{Q} 3(\right.$ Institution $\left.)\right] \times 0.29$

Finally, the difference: $\left(\left[\alpha_{1}+\alpha_{3} \times \mathrm{Q} 1(\right.\right.$ Institution $\left.)\right]-\left[\alpha_{1}+\alpha_{3} \times \mathrm{Q} 3(\right.$ Institution $\left.\left.)\right]\right) \times 0.29$ measures our economic significance of a one-standard-deviation increase in $C S R \_P(0.29)$ on $T O B Q$ after an

\begin{tabular}{|c|c|c|c|c|c|}
\hline & & $\begin{array}{c}\text { Stock } \\
\text { market } \\
\text { efficiency }\end{array}$ & $\begin{array}{l}\text { Credit } \\
\text { market } \\
\text { efficiency }\end{array}$ & $\begin{array}{l}\text { Business } \\
\text { freedom }\end{array}$ & $\begin{array}{c}\text { Legal } \\
\text { system \& } \\
\text { property } \\
\text { rights }\end{array}$ \\
\hline (1) & $\alpha_{1}$ & 0.753 & 0.557 & 0.922 & 1.143 \\
\hline (2) & $\alpha_{3}$ & -0.105 & -0.078 & -0.127 & -0.143 \\
\hline (3) & Q1(Institution) & 4.93 & 4.86 & 6.20 & 6.30 \\
\hline (4) & Q3(Institution) & 6.92 & 7.35 & 7.40 & 8.40 \\
\hline$(5)$ & $\begin{array}{l}\frac{\partial T O B Q}{\partial C S R} \text { evaluated at } \\
\mathrm{Q} 1(\text { Institution })=\alpha_{1}+\alpha_{3} \times \mathrm{Q} 1 \text { (Institution) }\end{array}$ & $\begin{array}{c}0.753- \\
0.105 \times 4.93 \\
=0.24\end{array}$ & $\begin{array}{l}0.557- \\
0.078 \times 4.86 \\
=0.18\end{array}$ & $\begin{array}{l}0.922- \\
0.127 \times 6.20 \\
=0.13\end{array}$ & $\begin{array}{c}1.143- \\
0.143 \times 6.30 \\
=0.24\end{array}$ \\
\hline (6) & $\begin{array}{l}\text { Effect of one-standard-deviation } \\
\text { increase in } C S R \quad P(0.29) \text { on } T O B Q \\
\text { evaluated at } Q 1(\text { Institution })=(5) \times 0.29\end{array}$ & 0.07 & 0.05 & 0.04 & 0.07 \\
\hline (7) & $\begin{array}{l}\frac{\partial T O B Q}{\partial C S R} \text { evaluated at } \\
\mathrm{Q} 3(\text { Institution })=\alpha_{1}+\alpha_{3} \times \mathrm{Q} 3(\text { Institution })\end{array}$ & $\begin{array}{c}0.753- \\
0.105 \times 6.92 \\
=0.03\end{array}$ & $\begin{array}{l}0.557- \\
0.078 \times 7.35 \\
=-0.02\end{array}$ & $\begin{array}{l}0.922- \\
0.127 \times 7.40 \\
=-0.02\end{array}$ & $\begin{array}{l}1.143- \\
0.143 \times 8.40 \\
=-0.06\end{array}$ \\
\hline (8) & $\begin{array}{l}\text { Effect of one-standard-deviation } \\
\text { increase in } C S R P P(0.29) \text { on } T O B Q \\
\text { evaluated at } \mathrm{Q} 3 \text { (Institution) }=(7) \times 0.29\end{array}$ & 0.01 & 0.00 & -0.01 & -0.02 \\
\hline (9) & $(8)-(6)$ & -0.06 & -0.06 & -0.04 & -0.09 \\
\hline
\end{tabular}
institutional change from the first to the third quartile.

Our calculations are summarized in the table below. 
Figure 1. Institutional voids, CSR, and firm value

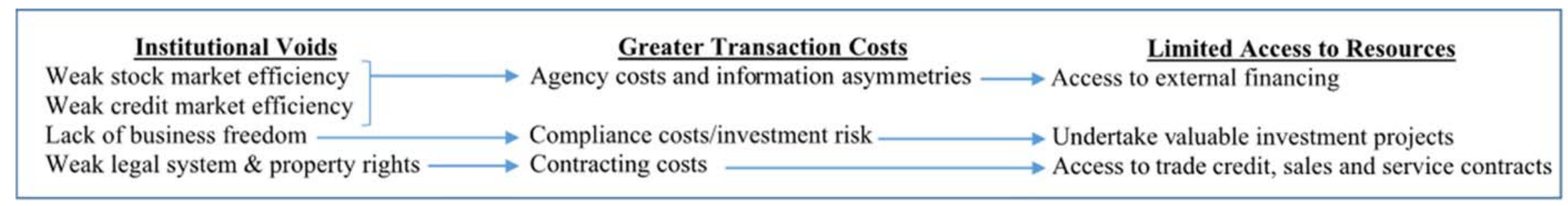

Greater strategic value of CSR

in countries with greater

institutional voids

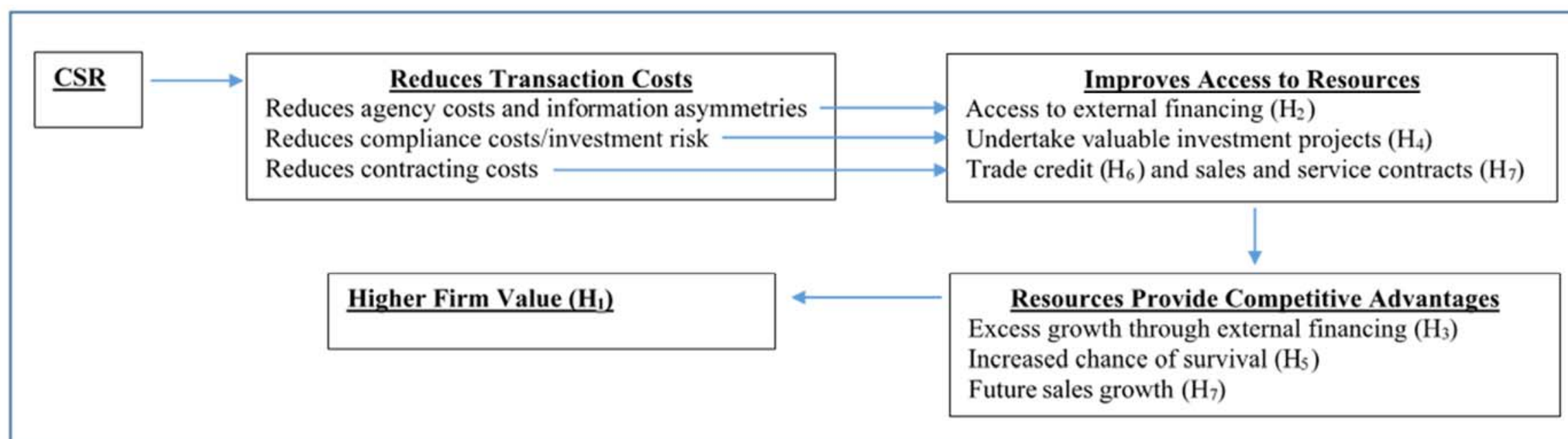


Table 1. Sample distribution

\begin{tabular}{|c|c|c|c|c|c|}
\hline \multicolumn{3}{|c|}{ Panel A. By country } & \multicolumn{3}{|c|}{ Panel A. By country (cont'd) } \\
\hline Country & $\mathrm{N}$ & $\%$ & Country & $\mathrm{N}$ & $\%$ \\
\hline Australia & 407 & 3.49 & Norway & 116 & 0.99 \\
\hline Austria & 87 & 0.75 & Panama & 1 & 0.01 \\
\hline Belgium & 117 & 1.00 & Papua New Guinea & 3 & 0.03 \\
\hline Brazil & 59 & 0.51 & Peru & 2 & 0.02 \\
\hline Canada & 670 & 5.74 & Philippines & 4 & 0.03 \\
\hline Chile & 17 & 0.15 & Poland & 11 & 0.09 \\
\hline China & 36 & 0.31 & Portugal & 53 & 0.45 \\
\hline Colombia & 2 & 0.02 & Qatar & 1 & 0.01 \\
\hline Czech Republic & 5 & 0.04 & Russian Federation & 26 & 0.22 \\
\hline Denmark & 115 & 0.99 & Saudi Arabia & 3 & 0.03 \\
\hline Egypt & 2 & 0.02 & Singapore & 126 & 1.08 \\
\hline Finland & 154 & 1.32 & South Africa & 22 & 0.19 \\
\hline France & 461 & 3.95 & Spain & 232 & 1.99 \\
\hline Germany & 384 & 3.29 & Sweden & 249 & 2.13 \\
\hline Greece & 99 & 0.85 & Switzerland & 287 & 2.46 \\
\hline Hong Kong & 114 & 0.98 & Thailand & 13 & 0.11 \\
\hline Hungary & 3 & 0.03 & Turkey & 18 & 0.15 \\
\hline India & 46 & 0.39 & United Arab Emirates & 8 & 0.07 \\
\hline Indonesia & 13 & 0.11 & United Kingdom & 1,442 & 12.35 \\
\hline Ireland & 86 & 0.74 & United States & 3,658 & 31.34 \\
\hline Israel & 20 & 0.17 & All countries & 11,672 & 100 \\
\hline Italy & 163 & 1.40 & & & \\
\hline Japan & 1,922 & 16.47 & \multicolumn{3}{|c|}{ Panel B. By year } \\
\hline Kazakhstan & 2 & 0.02 & Year & $\mathrm{N}$ & $\%$ \\
\hline Korea & 73 & 0.63 & 2003 & 644 & 5.52 \\
\hline Kuwait & 2 & 0.02 & 2004 & 651 & 5.58 \\
\hline Luxembourg & 42 & 0.36 & 2005 & 1,231 & 10.55 \\
\hline Malaysia & 21 & 0.18 & 2006 & 1,541 & 13.20 \\
\hline Mauritius & 3 & 0.03 & 2007 & 1,555 & 13.32 \\
\hline Mexico & 36 & 0.31 & 2008 & 1,697 & 14.54 \\
\hline Morocco & 2 & 0.02 & 2009 & 2,009 & 17.21 \\
\hline Netherlands & 183 & 1.57 & 2010 & 2,344 & 20.08 \\
\hline New Zealand & 51 & 0.44 & All years & 11,672 & 100 \\
\hline
\end{tabular}


Table 1 (cont'd).

\begin{tabular}{|c|c|c|c|c|c|}
\hline \multicolumn{6}{|c|}{ Panel C. By industry } \\
\hline Industry & $\mathrm{N}$ & $\%$ & Industry & $\mathrm{N}$ & $\%$ \\
\hline Agriculture & 30 & 0.26 & Aircraft & 125 & 1.07 \\
\hline Food Products & 335 & 2.87 & Shipbuilding \& Railroad Equipment & 31 & 0.27 \\
\hline Candy \& Soda & 48 & 0.41 & Defense & 9 & 0.08 \\
\hline Beer \& Liquor & 150 & 1.29 & Precious Metals & 106 & 0.91 \\
\hline Tobacco Products & 61 & 0.52 & Non-Metallic \& Industrial Metal Mining & 241 & 2.06 \\
\hline Recreation & 66 & 0.57 & Coal & 40 & 0.34 \\
\hline Entertainment & 115 & 0.99 & Petroleum \& Natural Gas & 746 & 6.39 \\
\hline Printing \& Publishing & 213 & 1.82 & Utilities & 692 & 5.93 \\
\hline Consumer Goods & 259 & 2.22 & Communication & 626 & 5.36 \\
\hline Apparel & 129 & 1.11 & Personal Services & 83 & 0.71 \\
\hline Healthcare & 103 & 0.88 & Business Services & 904 & 7.75 \\
\hline Medical Equipment & 205 & 1.76 & Computers & 260 & 2.23 \\
\hline Pharmaceutical Products & 419 & 3.59 & Electronic Equipment & 545 & 4.67 \\
\hline Chemicals & 510 & 4.37 & Measuring \& Control Equipment & 129 & 1.11 \\
\hline Rubber \& Plastic Products & 49 & 0.42 & Business Supplies & 175 & 1.50 \\
\hline Textiles & 21 & 0.18 & Shipping Containers & 50 & 0.43 \\
\hline Construction Materials & 296 & 2.54 & Transportation & 544 & 4.66 \\
\hline Construction & 404 & 3.46 & Wholesale & 331 & 2.84 \\
\hline Steel Works & 333 & 2.85 & Retail & 847 & 7.26 \\
\hline Fabricated Products & 10 & 0.09 & Restaurants, Hotels, Motels & 189 & 1.62 \\
\hline Machinery & 463 & 3.97 & Almost Nothing & 266 & 2.28 \\
\hline Electrical Equipment & 162 & 1.39 & & & \\
\hline Automobiles \& Trucks & 352 & 3.02 & All industries & 11,672 & 100 \\
\hline
\end{tabular}


Table 2. Descriptive statistics

\begin{tabular}{|c|c|c|c|c|c|}
\hline \multicolumn{6}{|l|}{ Panel A. By country } \\
\hline \multirow[b]{2}{*}{ Country } & \multirow[b]{2}{*}{$\mathrm{N}$} & \multicolumn{2}{|c|}{$T O B Q$} & \multicolumn{2}{|c|}{$C S R \_P$} \\
\hline & & Mean & $\mathrm{SD}$ & Mean & $\mathrm{SD}$ \\
\hline Australia & 407 & 1.92 & 1.20 & 0.45 & 0.27 \\
\hline Austria & 87 & 1.49 & 0.74 & 0.59 & 0.25 \\
\hline Belgium & 117 & 1.60 & 0.79 & 0.50 & 0.28 \\
\hline Brazil & 59 & 1.83 & 1.44 & 0.68 & 0.24 \\
\hline Canada & 670 & 1.76 & 0.97 & 0.40 & 0.26 \\
\hline Chile & 17 & 1.68 & 0.54 & 0.45 & 0.29 \\
\hline China & 36 & 1.90 & 1.39 & 0.32 & 0.25 \\
\hline Colombia & 2 & 2.52 & 0.42 & 0.67 & 0.01 \\
\hline Czech Republic & 5 & 1.54 & 0.12 & 0.73 & 0.11 \\
\hline Denmark & 115 & 2.09 & 1.36 & 0.48 & 0.25 \\
\hline Egypt & 2 & 1.10 & 0.02 & 0.10 & 0.00 \\
\hline Finland & 154 & 1.59 & 0.64 & 0.69 & 0.23 \\
\hline France & 461 & 1.56 & 0.82 & 0.75 & 0.23 \\
\hline Germany & 384 & 1.49 & 0.80 & 0.66 & 0.26 \\
\hline Greece & 99 & 1.74 & 1.18 & 0.48 & 0.30 \\
\hline Hong Kong & 114 & 1.61 & 0.79 & 0.45 & 0.28 \\
\hline Hungary & 3 & 1.09 & 0.08 & 0.90 & 0.03 \\
\hline India & 46 & 2.84 & 1.82 & 0.67 & 0.24 \\
\hline Indonesia & 13 & 3.53 & 1.40 & 0.64 & 0.19 \\
\hline Ireland & 86 & 1.88 & 1.10 & 0.37 & 0.20 \\
\hline Israel & 20 & 2.28 & 0.81 & 0.26 & 0.19 \\
\hline Italy & 163 & 1.46 & 0.56 & 0.55 & 0.31 \\
\hline Japan & 1,922 & 1.31 & 0.57 & 0.55 & 0.30 \\
\hline Kazakhstan & 2 & 1.25 & 0.27 & 0.19 & 0.01 \\
\hline Korea & 73 & 1.48 & 0.92 & 0.69 & 0.28 \\
\hline Kuwait & 2 & 1.70 & 0.48 & 0.39 & 0.03 \\
\hline Luxembourg & 42 & 1.76 & 1.10 & 0.48 & 0.23 \\
\hline Malaysia & 21 & 1.93 & 0.91 & 0.44 & 0.23 \\
\hline Mauritius & 3 & 0.89 & 0.18 & 0.30 & 0.06 \\
\hline Mexico & 36 & 1.72 & 0.89 & 0.56 & 0.35 \\
\hline Morocco & 2 & 3.29 & 0.14 & 0.52 & 0.04 \\
\hline Netherlands & 183 & 1.58 & 0.61 & 0.71 & 0.23 \\
\hline New Zealand & 51 & 1.73 & 1.09 & 0.44 & 0.22 \\
\hline Norway & 116 & 1.85 & 0.96 & 0.60 & 0.28 \\
\hline Panama & 1 & 1.31 & . & 0.12 & $\cdot$ \\
\hline Papua New Guinea & 3 & 2.36 & 0.28 & 0.40 & 0.25 \\
\hline Peru & 2 & 3.88 & 0.51 & 0.26 & 0.00 \\
\hline Philippines & 4 & 1.87 & 0.61 & 0.44 & 0.27 \\
\hline Poland & 11 & 1.58 & 1.16 & 0.40 & 0.19 \\
\hline
\end{tabular}




\begin{tabular}{|c|c|c|c|c|c|c|c|}
\hline Portugal & \multicolumn{2}{|c|}{53} & 1.51 & 0.55 & \multicolumn{2}{|c|}{0.70} & 0.22 \\
\hline Qatar & \multicolumn{2}{|c|}{1} & 2.70 & . & \multicolumn{2}{|c|}{0.19} & . \\
\hline Russian Federation & \multicolumn{2}{|c|}{26} & 2.02 & 1.36 & \multicolumn{2}{|c|}{0.40} & 0.24 \\
\hline Saudi Arabia & \multicolumn{2}{|c|}{3} & 1.34 & 0.28 & \multicolumn{2}{|c|}{0.29} & 0.25 \\
\hline Singapore & \multicolumn{2}{|c|}{126} & 1.71 & 0.75 & \multicolumn{2}{|c|}{0.35} & 0.21 \\
\hline South Africa & \multicolumn{2}{|c|}{22} & 2.41 & 1.30 & \multicolumn{2}{|c|}{0.63} & 0.24 \\
\hline Spain & \multicolumn{2}{|c|}{232} & 1.94 & 1.32 & \multicolumn{2}{|c|}{0.73} & 0.25 \\
\hline Sweden & \multicolumn{2}{|c|}{249} & 1.71 & 0.85 & \multicolumn{2}{|c|}{0.65} & 0.24 \\
\hline Switzerland & \multicolumn{2}{|c|}{287} & 2.14 & 1.13 & \multicolumn{2}{|c|}{0.60} & 0.29 \\
\hline Thailand & & & 1.97 & 0.62 & & & 0.28 \\
\hline Turkey & & & 2.06 & 1.44 & & & 0.27 \\
\hline United Arab Emirates & & & 1.52 & 0.29 & & & 0.08 \\
\hline United Kingdom & & & 1.78 & 0.92 & & & 0.24 \\
\hline United States & & & 1.99 & 1.09 & & & 0.28 \\
\hline All countries & & & 1.76 & 0.99 & & & 0.29 \\
\hline Panel B. For the full sam & & & & & & & \\
\hline Variable & Mean & Min & Q1 & $\begin{array}{c}\text { Media } \\
\text { n }\end{array}$ & Q3 & Max & SD \\
\hline$T O B Q_{t}$ & 1.76 & 0.73 & 1.13 & 1.43 & 2.00 & 6.29 & 0.99 \\
\hline Equity Issue $_{t}$ & 0.42 & 0.00 & 0.00 & 0.00 & 1.00 & 1.00 & 0.49 \\
\hline Excess Growth $_{t^{+1}}$ & 0.01 & -0.37 & -0.08 & -0.01 & 0.06 & 0.75 & 0.16 \\
\hline Debt Issue $_{t}$ & 0.39 & 0.00 & 0.00 & 0.00 & 1.00 & 1.00 & 0.49 \\
\hline Investment $_{t}$ & 0.23 & 0.02 & 0.12 & 0.18 & 0.28 & 1.32 & 0.20 \\
\hline Bankruptcy $_{t}$ & 0.04 & 0.00 & 0.00 & 0.00 & 0.00 & 0.84 & 0.15 \\
\hline Payable Turnover ${ }_{t}$ & 8.85 & 0.79 & 4.52 & 6.97 & 10.07 & 59.20 & 8.16 \\
\hline Sales Growth $_{t+1}$ & 0.07 & -0.34 & -0.02 & 0.05 & 0.13 & 0.80 & 0.17 \\
\hline$C S R \_P_{t-1}$ & 0.53 & 0.07 & 0.25 & 0.52 & 0.82 & 0.98 & 0.29 \\
\hline$S I Z E_{t-1}$ & 8.63 & 1.69 & 7.72 & 8.53 & 9.52 & 13.59 & 1.36 \\
\hline$R O A_{t-1}$ & 0.14 & -0.07 & 0.09 & 0.12 & 0.18 & 0.44 & 0.08 \\
\hline$L E V_{t-1}$ & 0.19 & 0.00 & 0.07 & 0.17 & 0.28 & 0.65 & 0.15 \\
\hline$R \& D / S_{t-1}$ & 0.03 & 0.00 & 0.00 & 0.00 & 0.02 & 0.31 & 0.06 \\
\hline$S G R_{t-1}$ & 0.09 & -0.48 & -0.02 & 0.06 & 0.16 & 1.38 & 0.25 \\
\hline$L O G_{-} G D P_{t-1}$ & 10.28 & 6.51 & 10.16 & 10.48 & 10.55 & 10.94 & 0.49 \\
\hline Stock market efficiency ${ }_{t-1}$ & 5.97 & 2.26 & 4.93 & 6.10 & 6.92 & 9.07 & 1.32 \\
\hline Credit market efficiency ${ }_{t-1}$ & 6.04 & 1.98 & 4.86 & 6.18 & 7.35 & 8.82 & 1.56 \\
\hline Business freedom ${ }_{t-1}$ & 6.74 & 3.50 & 6.20 & 6.70 & 7.40 & 9.00 & 0.95 \\
\hline $\begin{array}{l}\text { Legal system \& property } \\
\text { rights }_{t-1}\end{array}$ & 7.29 & 3.90 & 6.30 & 7.50 & 8.40 & 9.50 & 1.34 \\
\hline
\end{tabular}


Table 3. Corporate social responsibility and firm value

\begin{tabular}{lcccc}
\hline Institution: & $\begin{array}{c}\text { Stock market } \\
\text { efficiency }\end{array}$ & $\begin{array}{c}\text { Credit market } \\
\text { efficiency }\end{array}$ & $\begin{array}{c}\text { Business } \\
\text { freedom }\end{array}$ & $\begin{array}{c}\text { Legal system \& } \\
\text { property rights }\end{array}$ \\
\cline { 2 - 5 } CSR_P $P_{t-1}$ & $(1)$ & $(2)$ & $(3)$ & $(4)$ \\
& $0.753^{* * *}$ & $0.557^{* * *}$ & $0.922^{* * *}$ & $1.143^{* *}$ \\
Institution $_{t-1}$ & $(4.904)$ & $(4.486)$ & $(3.733)$ & $(2.571)$ \\
& $0.109^{* * *}$ & $0.075^{* * *}$ & $0.072^{*}$ & $0.149^{* * *}$ \\
$C S R_{-} P_{t-1} \times$ Institution $_{t-1}$ & $(5.690)$ & $(5.678)$ & $(1.945)$ & $(3.160)$ \\
$S I Z E_{t-1}$ & $-0.105^{* * *}$ & $-0.078^{* * *}$ & $-0.127^{* * *}$ & $-0.143^{* *}$ \\
& $(-4.844)$ & $(-4.603)$ & $(-3.597)$ & $(-2.517)$ \\
$R O A_{t-1}$ & $-0.378^{* * *}$ & $-0.375^{* * *}$ & $-0.376^{* * *}$ & $-0.375^{* * *}$ \\
& $(-11.869)$ & $(-11.884)$ & $(-11.712)$ & $(-11.741)$ \\
$L E V_{t-1}$ & $0.813^{* * *}$ & $0.807^{* * *}$ & $0.799^{* * *}$ & $0.796^{* * *}$ \\
& $(4.176)$ & $(4.151)$ & $(4.134)$ & $(4.129)$ \\
$R \& D / S_{t-1}$ & $-0.193^{*}$ & -0.181 & -0.187 & $-0.196^{*}$ \\
$S G R_{t-1}$ & $(-1.654)$ & $(-1.549)$ & $(-1.588)$ & $(-1.664)$ \\
& -0.021 & 0.006 & 0.084 & 0.031 \\
$L O G_{-} G D P_{t-1}$ & $(-0.027)$ & $(0.008)$ & $(0.109)$ & $(0.041)$ \\
Year effects & 0.050 & 0.052 & 0.058 & 0.054 \\
Firm effects & $(1.359)$ & $(1.410)$ & $(1.551)$ & $(1.461)$ \\
Observations & 0.731 & 0.731 & $1.111^{* *}$ & $1.155^{* *}$ \\
R-squared & $(1.531)$ & $(1.531)$ & $(2.297)$ & $(2.399)$ \\
\hline
\end{tabular}

This table reports results from regressing Tobin's q $(T O B Q)$ on CSR performance $\left(C S R \_P\right)$ and interactions between CSR performance and the four proxies for country-level institutions. All models include firm and year fixed effects. Appendix A provides definitions and data sources for all variables. $t$-statistics based on robust standard errors adjusted for clustering by firm are in parentheses. ${ }^{* *}, * *$, and $*$ denote statistical significance at the $1 \%, 5 \%$, and $10 \%$ levels, respectively. 
Table 4. Corporate social responsibility and firm value: Channels

\begin{tabular}{|c|c|c|c|c|c|c|c|c|}
\hline \multirow{2}{*}{$\begin{array}{l}\text { Institution: } \\
\text { Dependent variable: }\end{array}$} & \multicolumn{2}{|c|}{$\begin{array}{c}\text { Stock market } \\
\text { efficiency }\end{array}$} & \multicolumn{2}{|c|}{$\begin{array}{c}\text { Credit market } \\
\text { efficiency }\end{array}$} & \multicolumn{2}{|c|}{ Business freedom } & \multicolumn{2}{|c|}{$\begin{array}{c}\text { Legal system \& } \\
\text { property rights }\end{array}$} \\
\hline & Equity Issue $_{t}$ & $\begin{array}{c}\text { Excess } \\
\text { Growth }_{t+1}\end{array}$ & Debt Issue $_{t}$ & $\begin{array}{c}\text { Excess } \\
\text { Growth }_{t+1}\end{array}$ & Investment $_{t}$ & Bankruptcy $_{t}$ & $\begin{array}{l}\text { Payable } \\
\text { Turnover }_{t}\end{array}$ & $\begin{array}{c}\text { Sales } \\
\text { Growth }_{t+1} \\
\end{array}$ \\
\hline \multirow{3}{*}{$C S R \_P_{t-1}$} & $(1)$ & (2) & (3) & (4) & (5) & $(6)$ & $(7)$ & $(8)$ \\
\hline & $1.288^{* *}$ & $0.068^{*}$ & $1.720 * * *$ & $0.054^{*}$ & $0.225 * * *$ & $-0.186^{* *}$ & $-8.987 * *$ & $0.257^{*}$ \\
\hline & $(2.055)$ & $(1.693)$ & $(3.579)$ & $(1.720)$ & $(2.855)$ & $(-2.473)$ & $(-2.254)$ & $(1.900)$ \\
\hline \multirow[t]{2}{*}{ Institution $_{t-l}$} & 0.053 & $0.020 * * *$ & $0.193 * * *$ & $0.009 * * *$ & 0.002 & $-0.073 * * *$ & -0.300 & $0.026^{*}$ \\
\hline & $(0.712)$ & $(4.156)$ & $(3.745)$ & $(3.117)$ & $(0.146)$ & $(-6.265)$ & $(-0.678)$ & $(1.769)$ \\
\hline \multirow{2}{*}{$C S R \_P_{t-1} \times$ Institution $_{t-1}$} & $-0.278 * * *$ & $-0.013^{* *}$ & $-0.204 * * *$ & $-0.012 * * *$ & $-0.029 * *$ & $0.027 * * *$ & $1.175^{* *}$ & $-0.037 * *$ \\
\hline & $(-3.065)$ & $(-2.442)$ & $(-3.073)$ & $(-2.814)$ & $(-2.561)$ & $(2.749)$ & $(2.317)$ & $(-2.152)$ \\
\hline \multirow[t]{2}{*}{$S I Z E_{t-1}$} & $-1.123 * * *$ & $-0.144 * * *$ & $-0.843 * * *$ & $-0.144 * * *$ & $-0.088 * * *$ & 0.003 & $0.540 * *$ & $-0.173 * * *$ \\
\hline & $(-10.978)$ & $(-9.494)$ & $(-8.572)$ & $(-9.419)$ & $(-7.128)$ & $(0.621)$ & $(2.256)$ & $(-10.965)$ \\
\hline \multirow{2}{*}{$R O A_{t-1}$} & 0.199 & $-0.732 * * *$ & $4.015^{* * *}$ & $-0.735 * * *$ & $0.267 * * *$ & -0.006 & 1.362 & $-0.570 * * *$ \\
\hline & $(0.325)$ & $(-10.234)$ & $(6.350)$ & $(-10.257)$ & $(4.824)$ & $(-0.254)$ & $(0.959)$ & $(-8.289)$ \\
\hline \multirow{2}{*}{$L E V_{t-1}$} & $1.636^{* * *}$ & 0.011 & $-6.599 * * *$ & 0.012 & $-0.156 * * *$ & -0.028 & 0.554 & 0.041 \\
\hline & $(4.464)$ & $(0.356)$ & $(-16.112)$ & $(0.389)$ & $(-5.152)$ & $(-1.502)$ & $(0.594)$ & $(1.364)$ \\
\hline \multirow[t]{2}{*}{$R \& D / S_{t-1}$} & 0.269 & $0.295^{* *}$ & 0.229 & $0.306^{* *}$ & $-0.366 * *$ & $-0.111 * *$ & -1.939 & $0.354 * * *$ \\
\hline & $(0.181)$ & $(2.449)$ & $(0.143)$ & $(2.550)$ & $(-2.359)$ & $(-2.425)$ & $(-0.283)$ & $(2.792)$ \\
\hline \multirow[t]{2}{*}{$S G R_{t-1}$} & -0.088 & $-0.039 * * *$ & $-0.477 * * *$ & $-0.039 * * *$ & $0.037 * * *$ & $0.011^{* *}$ & 0.373 & $-0.024 * *$ \\
\hline & $(-0.724)$ & $(-3.521)$ & $(-3.777)$ & $(-3.496)$ & $(3.255)$ & $(2.020)$ & $(1.012)$ & $(-2.152)$ \\
\hline \multirow{2}{*}{$L O G_{-} G D P_{t-1}$} & $5.636^{* * *}$ & 0.207 & $4.084 * *$ & $0.265^{*}$ & $0.414 * * *$ & -0.082 & -3.580 & $0.264 *$ \\
\hline & $(3.542)$ & $(1.356)$ & $(2.462)$ & $(1.725)$ & $(3.320)$ & $(-1.645)$ & $(-0.932)$ & (1.674) \\
\hline Year effects & Yes & Yes & Yes & Yes & Yes & Yes & Yes & Yes \\
\hline Firm effects & Yes & Yes & Yes & Yes & Yes & Yes & Yes & Yes \\
\hline Observations & 8,994 & 9,505 & 9,639 & 9,505 & 11,621 & 8,835 & 11,265 & 9,539 \\
\hline R-squared & . & 0.276 & . & 0.275 & 0.135 & 0.111 & 0.021 & 0.336 \\
\hline \multicolumn{9}{|c|}{$\begin{array}{l}\text { This table reports results from regressing firm-level outcomes on CSR performance }\left(C S R \_P\right) \text { and interactions between CSR } \\
\text { performance and the four proxies for country-level institutions. All models include firm and year fixed effects. Columns (1) } \\
\text { and (3) are estimated using logit regressions and do not have an R-squared. Appendix A provides definitions and data sources } \\
\text { for all variables. } t \text {-statistics based on robust standard errors adjusted for clustering by firm are in parentheses. } * * *, * * \text {, and } * \\
\text { denote statistical significance at the } 1 \%, 5 \% \text {, and } 10 \% \text { levels, respectively. }\end{array}$} \\
\hline
\end{tabular}

